\title{
Variability in the crystallographic texture of bivalve nacre
}

\author{
JIŘí FrÝda, MAGdalena KLICNAROVÁ, BARBORA FrÝDOVÁ \& MICHAL MERGL
}

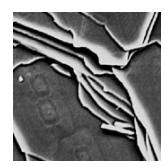

The crystallographic texture of nacre in eleven bivalve species belonging to the superorders Opponobranchia, Pteriomorpha, and Paleoheterodonta, was studied. Our analysis confirmed a uniform orientation of the crystallographic $c$-axes of aragonite platelets in all the species studied, but a variable arrangement of $a$-and $b$-axes. New data suggest that the rate of alignment of $a$ - and $b$-axes from girdle-like (unordered nacre) to a single crystal-like texture (ordered nacre) differs considerably among the analyzed species. Numerical evaluation of the data obtained from species with ordered nacre also revealed systematic differences in texture strength among the main crystallographic axes of aragonite platelets. The texture strength of $a$-axes (direction parallel to growth lines) is always weaker than that of $b$ - and $c$-axes. Observed differences in shape of the growth lines on the surface of nacreous platelets, in twinning percentage as well as in rate of alignment of $a$ - and $b$-axes suggest variations in nacre growth process in individual phylogenetic lineages of the Class Bivalvia. These facts may imply not only evolutionary changes in microstructure and crystallographic texture of the nacre but also in molecular mechanisms driving its production during the long molluscan evolution. $\bullet$ Key words: Bivalvia, nacre, crystallographic texture, phylogeny.

FrÝdA, J., KLICNAROVÁ, K., FrÝDOVÁ, B. \& MERGL, M. 2010. Variability in the crystallographic texture of bivalve nacre. Bulletin of Geosciences 85(4), 645-662 (9 figures). Czech Geological Survey, Prague. ISSN 1214-1119. Manuscript received October 18, 2010; accepted in revised form December 6, 2010; published online December 13, 2010; issued December 20, 2010.

Jiři Frýda, Czech Geological Survey, P.O.B. 85, 11821 Prague 1, and Faculty of Environmental Sciences, Czech University of Life Sciences Prague, Kamýcká 129, 16521 Praha 6-Suchdol, Czech Republic; bellerophon@seznam.cz• Magdalena Klicnarová, Faculty of Environmental Sciences, Czech University of Life Sciences Prague, Kamýcká 129, 16521 Praha 6 - Suchdol, Czech Republic • Barbora Frýdová, VÚRV v.v.i., Research Institute, Drnovská 507, 16106 Prague - Ruzyně, Czech Republic • Michal Mergl, University of West Bohemia, Faculty of Education, Department of Biology, Klatovská 51, 30619 Plzeň, Czech Republic; mmergl@kbi.zcu.cz.

The study of biologically controlled mineralization is one of topics connecting scientists with quite different methodological approaches, such as material physicists, zoologists, molecular biologists, paleontologists and medical doctors. The fact that molecular mechanisms in some organisms may control and produce at low temperature perfectly organized structures on a nanoscale is a great inspiration for material scientists. The formation of molluscan shells is one of the most studied cases of biologically controlled mineralization. Molluscan shells consist mainly of calcium carbonate crystals (aragonite and/or calcite, rarely vaterite) with a small amount of other organic substances. The carbonate mono- or polycrystals forming these shells are organized into many different microstructures and textures (see Carter 1990a, b). It has been shown several times that the style of nanoscale organization of inorganic and organic components of the molluscan shells considerably changes their physical properties (e.g., Bertoldi et al. 2008, Denkena et al. 2010, Ouhenia et al. 2008a, Chateigner et al. 2010). Understanding of the biomineralization processes on a molecular level should make preparation of new nanocomposites possible in the future.

The molecular mechanism determining the shape and orientation of individual calcium carbonate crystals in molluscan shells is very complex and still not well understood even though it had been intensively studied during the last three decades. Recent studies showed that molluscan shell mineralization is a very complex process in which different shell proteins play a very important role (e.g., Marin \& Luquet 2004; Marie et al. 2008, 2009; Ouhenia et al. 2008b; see excellent review by Marin et al. 2008). Biochemical studies produced evidence of the active role of some macromolecules in control of the polymorphism of calcium carbonate. It was shown that macromolecules extracted from the aragonite shell layer induced the growth of aragonite in vitro on a substrate of polysaccharide $b$-chitin and hydrophobic silk protein (e.g., Falini et al. 1996). Recently a team of Japanese scientists (Suzuki et al. 2009) reported a discovery of two novel proteins, named Pif80 and Pif97, which seem to be the key players in controlling the crystal structure of nacre in pearl-forming oysters. 
During the last decades, biochemical studies have thus produced many significant insights into the mechanisms of shell formation on the molecular level. As has been previously shown, that each particular shell microstructure is very complex nanocomposite which is also the product of a very complex molecular mechanism. Because of this a parallel development of shell layer with the same microstructure and texture is highly unlikely. Better understanding of the relationships between particular molecular processes on the one hand and microstructure and texture of individual shell layers on the other hand will thus produce a new data source for understanding the long evolution of molluscs. Inorganic and organic components of molluscan shells and their functions may be studied only in living molluscs. However the extremely rich and diverse fossil record of molluscan evolution gives the chance to study only inorganic biomineralization products, i.e., molluscan shells. Individual molluscan shell layers may be characterized by their shell microstructure, phase composition, and crystallographic texture. The shell microstructure, characterizing the shape of biocrystals, has been the most studied property of molluscan shells. On the other hand, there are almost no data on crystallographic textures of particular shell layers of living as well as fossil molluscs. The crystallographic texture describing the arrangement of crystal axes of individual biocrystals thus provides non-redundant characteristics of a particular shell layer.

In this short paper we present the results of crystallographic texture analysis of nacre in eleven bivalve species belonging to three different superorders. The main goal of this short study was to test how variable are the crystallographic texture characteristics of bivalve nacre (i.e., quantitatively evaluate texture pattern of the bivalve nacre and percentage of twinning of nacreous platelets).

\section{Material and methods}

The present study is based on crystallographic texture analysis of nacre in eleven bivalve species belonging to superorders Opponobranchia Giribet, 2008, Pteriomorpha Beurlen, 1944, and Paleoheterodonta Newell, 1965, all of which develope a nacreous layer in their shells. Order Nuculida Dall, 1889 (Opponobranchia Giribet, 2008) was characterized by the common species Nucula nucleus (Linnaeus, 1758), from the Mediterranean Sea coast near Dénia (80 km SE of Valencia, Spain). Members of two bivalve orders, Mytilida Férussac, 1822 and Pteriida Newell, 1965 were chosen to characterize the superorder Pteriomorpha Beurlen, 1944. Five species from, three genera, Mytilus Linnaeus, 1758, Modiolus Lamarck, 1799, Brachidontes Swainson, 1840, of order Mytilida were studied. Three of these species belong to the genus Mytilus: Mytilus edulis Linnaeus, 1758 from two localities [from (1) the English
Channel coast near Brighton, England, and from (2) the North Sea, Slemmestad near Oslo, Sweden], Mytilus galloprovincialis Lamarck, 1819, from the Adriatic Sea near the town of Rabac, Istria, Croatia, and Mytilus californianus (Conrad, 1837), from the coast of the Pacific Ocean near the town of Brookings, SW Oregon, U.S.A. The genus Modiolus Lamarck, 1799, is represented by the species Modiolus barbatus (Linnaeus, 1758), from the Adriatic Sea near the village of Izola, Slovenia, and the genus Brachidontes Swainson, 1840, by the species Brachidontes rostratus (Dunker, 1857), from Brouler Beach near Sydney, NSW, Australia. Two species of genera Pinctada Roding, 1798, and Pinna Linnaeus, 1758 from the order Pteriida were studied: Pinctada radiata (Leach, 1814), from the Mediterranean Sea, Karpathos island, Greece, and Pinna nobilis (Linnaeus, 1758), from two localities [(1) the coast of the Mediterranean Sea near Dénia, $80 \mathrm{~km}$ SE of Valencia, Spain, and (2) the Adriatic Sea near the village of Izola, Slovenia]. Three freshwater species of unionid genera, Amblema Rafinesque, 1820, Leptodea Rafinesque, 1820, and Quadrula Rafinesque, 1820, were selected to characterize the superorder Heteroconchia Cox, 1960: Amblema plicata (Say, 1817), Leptodea fragilis (Rafinesque, 1820), and Quadrula apiculata (Say, 1829), all coming from NW Texas.

Bivalve shells selected for crystallographic texture analysis were gently broken to preserve information on the biological orientation of each which may be valuable in future research. Several shell fragments of each species were studied under SEM (Figs 1-3) and special attention was paid to lateral thickness variability of the nacreous layer. Fragments with the thickest nacreous layer were used for crystallographic texture analysis and separately embedded in epoxy resin. The biological orientation of each shell fragment was marked on the surface of the surrounding epoxy resin block. Subsequently, each shell fragment was polished using a progressively finer polishing medium (down to $5 \mu \mathrm{m}$ grit $\mathrm{SiC}$ followed by several minutes with $3 \mu \mathrm{m}$ diamond, $1 \mu \mathrm{m}$ diamond, $0.25 \mu \mathrm{m}$ diamond, and 5 minutes with $0.05 \mu \mathrm{m}$ colloidal silica). Each shell fragment was polished parallel to the inner shell surface and to a level cutting roughly to the middle of the nacreous shell layer (i.e., area having the same distance from inner surface of the nacreous layer as well as from boundary between the nacreous and outer prismatic layers). Samples were cleaned in an ultrasonic bath, dried at room temperature, and then carbon coated. Electron Backscatter Diffraction (EBSD) analysis was carried out in the Department of Geochemistry at the Czech Geological Survey using a Nordlys detector connected to a CamScan scanning electron microscope. The diffracted backscatter electrons producing a series of Kikuchi bands were collected by the Nordlys detector, and the crystallographic orientation of each measured nacreous platelet was evaluated by the EBSD acquisition software Channel 5 (HKL Technology). Measurements 

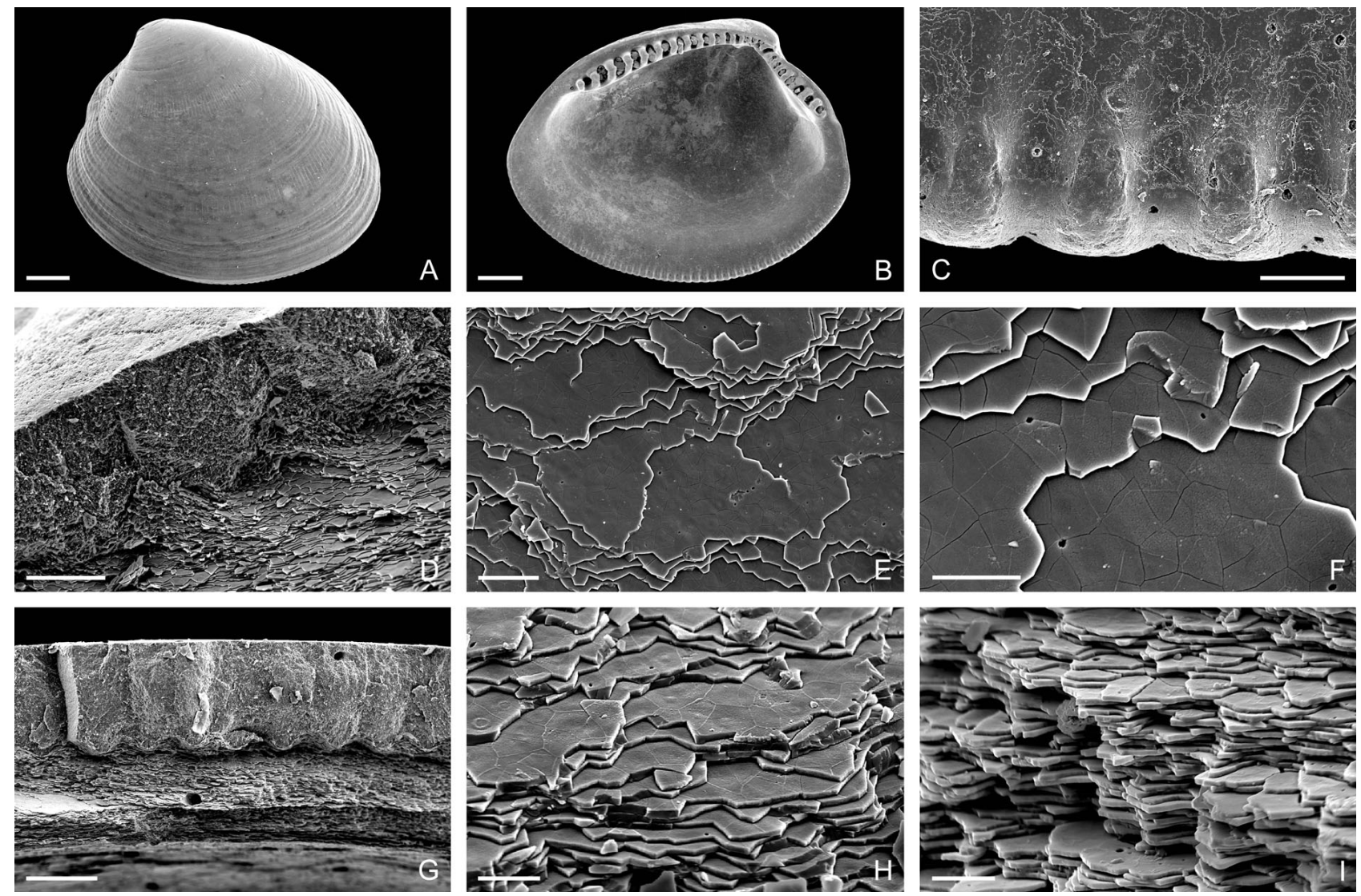

Figure 1. Secondary electron images of Nucula nucleus (Linnaeus, 1758) from the Mediterranean Sea near Dénia, $80 \mathrm{~km}$ SE of Valencia, Spain. - A, B - overall view of shell showing its outer (A) and inner (B) surface. $\bullet$ C - detailed view of inner surface near shell margin showing initial deposition of nacreous layer. $\bullet D, G-$ detailed views of broken shell showing prismatic (above) and nacreous (below) layers. $\bullet$ E - views of nacreous layer perpendicular to shell surface. $\bullet \mathrm{F}$ - detailed view of sample figured as $\mathrm{E}$ showing shape of nacreous platelets. $\bullet \mathrm{H}$, I - oblique views of nacreous layer with platelets arranged in a brick-wall microstructure. Scale bars: A, B - $1 \mathrm{~mm} ; \mathrm{C}, \mathrm{G}-100 \mu \mathrm{m} ; \mathrm{D}-50 \mu \mathrm{m} ; \mathrm{E}-20 \mu \mathrm{m} ; \mathrm{F}, \mathrm{H}, \mathrm{I}-10 \mu \mathrm{m}$.

were carried out on each nacre fragment on a regular grid with a spacing of $15 \mu \mathrm{m}$. The analyzed area forms a square situated roughly in the place where the polished surface cuts through the middle of the nacreous layer. In small shells (because of their curvature) the margins of the analyzed area could also include some nacreous platelets farther from the plane cutting through the middle of the nacreous layer. However, in such cases the analyzed area was much less than one square millimeter and so all the analyzed platelets were close to the middle of the nacreous layer. Size and shape of the nacreous platelets in bivalve shells (Figs 1-3) is more variable than those in gastropod and cephalopod shells. The majority of nacreous platelets in the analyzed bivalve species were less than $10 \mu \mathrm{m}$ in size (Figs 1-3) and so the number of measurements roughly corresponds to the number of measured nacreous platelets in each shell fragment.

The orientation of each measured nacreous platelet was calculated and expressed as three Euler angles by the software Channel 5 (HKL Technology). These values were subsequently recalculated as nine direct cosines for three basic crystallographic directions of aragonite (i.e., [100], [010], and [001]) and crystallographic direction [101] by the software package Škeble. These crystallographic directions were plotted on a stereographic projection (Figs 4, 6, 8) using the commercial software Spheristat (Pangaea Scientific). For the main crystallographic directions, three eigenvectors were calculated (their directions and magnitudes). Eigenvalues were then used for the calculation of two Woodcock's ratios ( $\mathrm{C}$ and $\mathrm{K}$ ) which, in turn, served for numerical evaluation of a textural type and strength of texture for each group of studied crystallographic vectors (Woodcock 1977). The $\mathrm{C}$ value is defined as $\ln (\mathrm{E} 3 / \mathrm{E} 1)$ and the $\mathrm{K}$ value as $\ln (\mathrm{E} 3 / \mathrm{E} 2) / \ln (\mathrm{E} 2 / \mathrm{E} 1)$, where $\mathrm{E} 1, \mathrm{E} 2$, and $\mathrm{E} 3$ are eigenvalues. Basic textural types may be described by these two Woodcock's ratio values. The $\mathrm{K}$ value characterizes the textural type (see terminology in Fig. 7F) and the $\mathrm{C}$ value measures texture strength. The $K$ value measures the girdle and cluster tendencies, where $\mathrm{K}>1$ indicates a cluster and $\mathrm{K}<1$, a girdle. The strength measurements depends on a critical value, $\mathrm{C}_{95}$, which was calculated by the Woodcock-Naylor uniformity test (Woodcock \& Naylor 1983). The Woodcock's ratio values were plotted on a modified Flinn diagram (Fig. 7). 

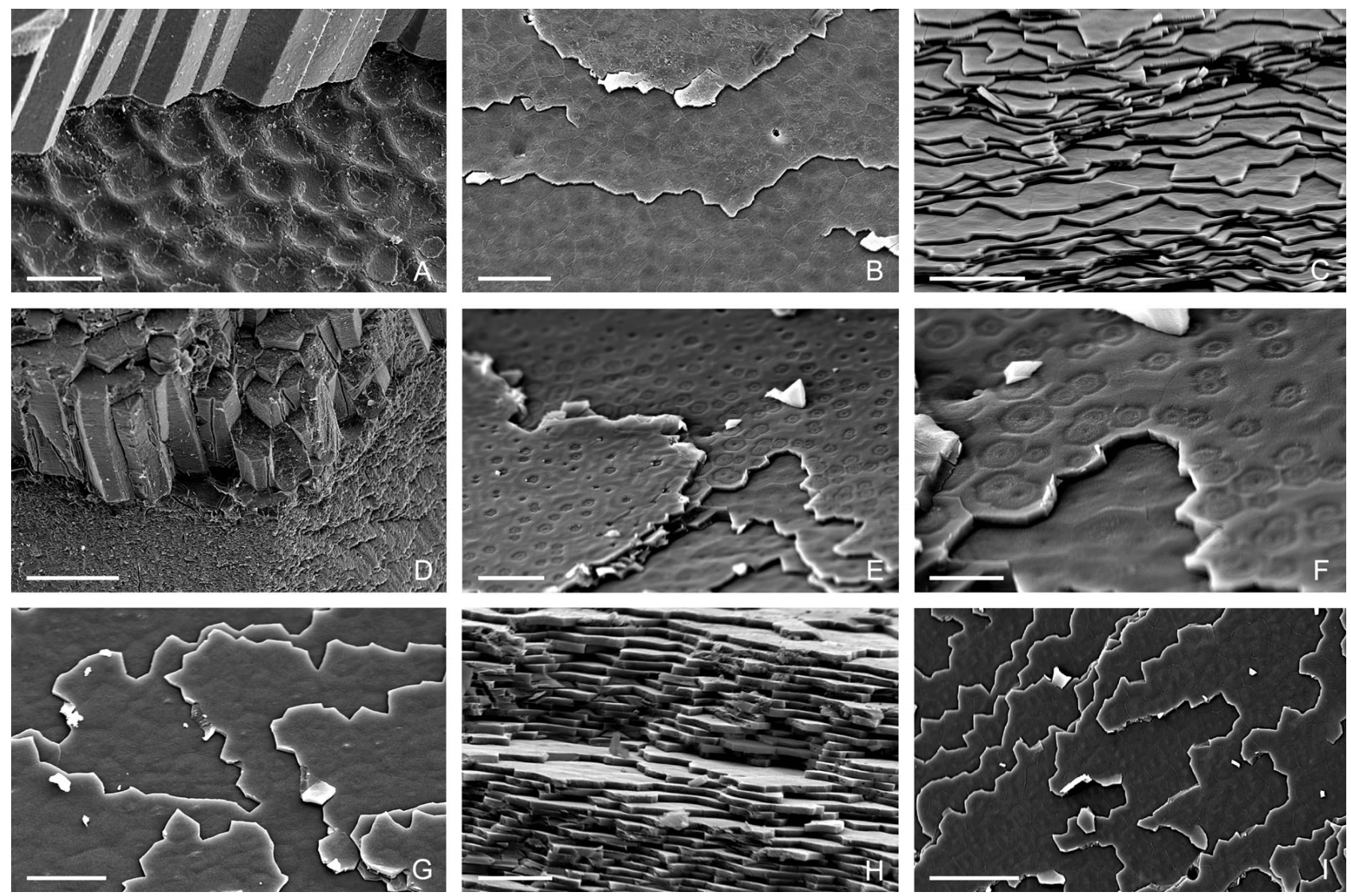

Figure 2. Secondary electron images of shell microstructures in (A) Amblema plicata, (E, F) Quadrula apiculata, and (G) Leptodea fragilis from NW Texas, (B) Mytilus californianus from coast of Pacific Ocean, SW Oregon, (C, D, I) Pinctada radiata from the Mediterranean Sea, Karpathos island, Greece, and (H) Mytilus edulis from the English Channel coast near Brighton, England. • A - Amblema plicata (Say, 1817), oblique view of boundary between nacreous (bellow) and outer prismatic (above) layers. $\bullet$ B - Mytilus californianus (Conrad, 1837), view of nacreous layer perpendicular to shell surface showing shape and size individual platelets. $\bullet$ C, D, I - Pinctada radiata (Leach, 1814), oblique (C) and perpendicular (I) views of nacreous layers; (D) boundary between nacreous (below) and outer prismatic (above) layers. $\bullet$ E, F - Quadrula apiculata (Say, 1829), oblique view of nacreous platelets showing growth lines in form of very regular hexagons. $\bullet \mathrm{G}-$ Leptodea fragilis (Rafinesque, 1820 ), view of nacreous layer perpendicular to shell surface showing shape and size individual platelets. $\bullet \mathrm{H}-$ Mytilus edulis Linnaeus, 1758 , oblique views of nacreous layer. Scale bars: A - 50 $\mu$ m; B, C, E, G, H$10 \mu \mathrm{m} ; \mathrm{D}-100 \mu \mathrm{m} ; \mathrm{F}-5 \mu \mathrm{m} ; \mathrm{I}-20 \mu \mathrm{m}$.

In textures having twin-like patterns, the relative fractions associated with each component of the twin were counted. Double twinning exhibits six maxima for [100] and [101] (Figs 4, 6, 8). The percentage of twinned aragonite platelets was calculated as the ratio of twinned platelets to the number of all measured platelets for both orientations of twinning.

\section{Results}

The SEM results revealed a well-preserved nacreous layer in all the studied bivalve species (Figs 1-3). The thickness of the nacreous platelets was constant within each species studied and varied slightly between different species. Generally it was about $1 \mu \mathrm{m}$ or less, but in the fresh-water unionid Leptodea fragilis (Rafinesque, 1820) the thickness of individual nacreous platelets was distinctly greater than $1 \mu \mathrm{m}$ (Fig. 3B, C). Shape and size of bivalve nacreous plateles was more variable (Figs 1-3) than those in gastropod or cephalopods. In two species, Pinna nobilis (Linnaeus, 1758) and Quadrula apiculata (Say, 1829), differing types of growth lines on the surface of the nacreous platelets were observed. The growth lines formed an elongated rectangle with rounded angles in Pinna nobilis (Fig. 3E), but formed very regular hexagons in Quadrula apiculata (Fig. 2E, F).

Analysis of the crystallographic texture of the nacreous layer confirmed that the crystallographic direction [001] ( $c$-axis of aragonite) is perpendicular to the inner shell surface in all the studied bivalve species (Figs 4, 6, 8). The value of Woodcock's $\mathrm{K}$ for this crystallographic direction in the nacre in all the species studied varied between 3.34 and 75.5, and Woodcock's $C$ values for the same direction varied between 3.83 and 6.37. Thus, Woodcock's $C$ values are much higher than the critical value $\mathrm{C}_{95}(0.15-0.29)$ for a uniform distribution (significance level 0.05), as well as higher than the value defining the boundary between a 

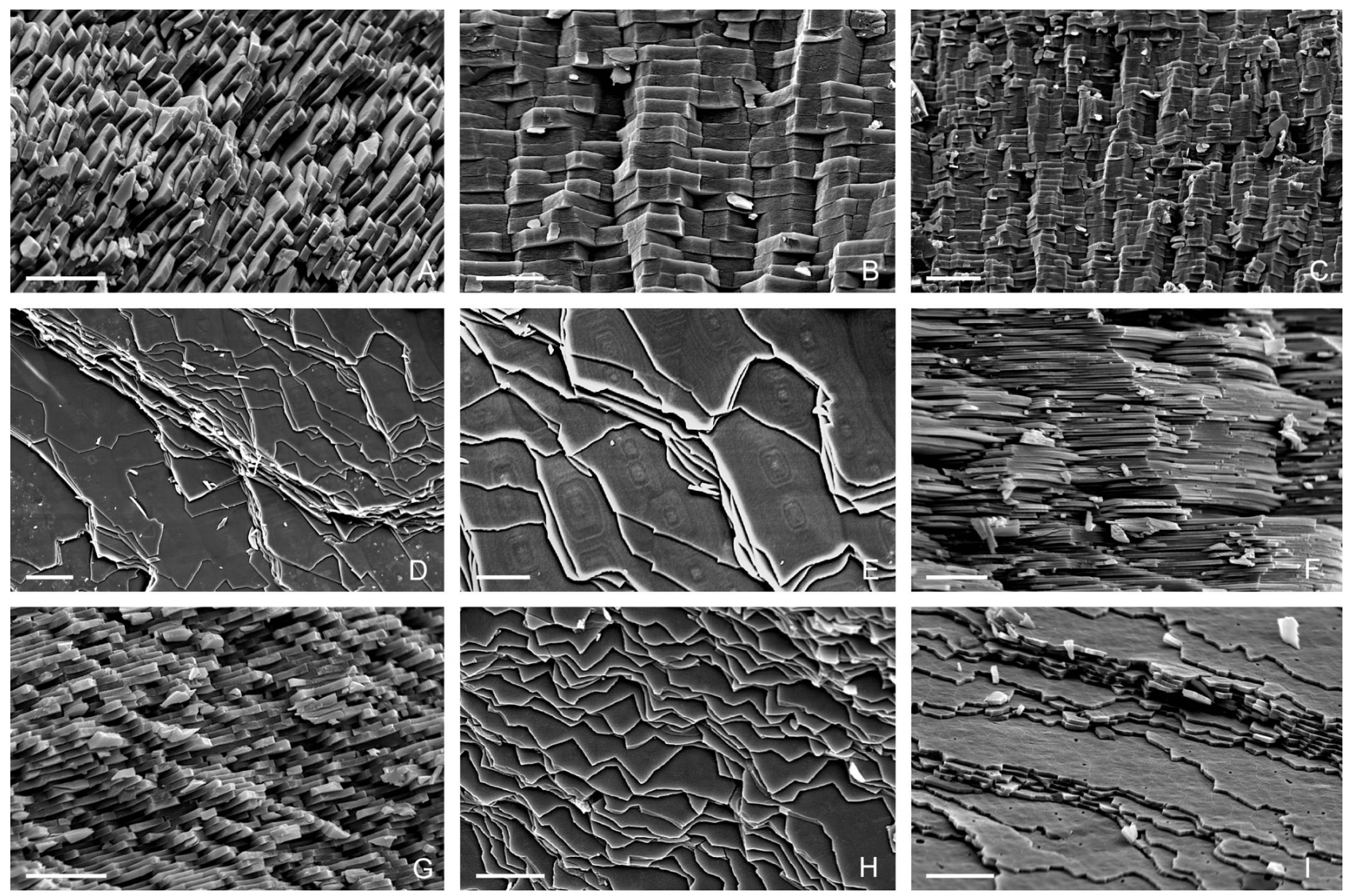

Figure 3. Secondary electron images of shell microstructures in (A, H) Mytilus edulis from North Sea, Slemmestad near Oslo, Sweden, (B, C) Leptodea fragilis and (G) Quadrula apiculata from NW Texas, (D-F) Pinna nobilis and (I) Modiolus barbatus from coast of Adriatic Sea near Izola village, Slovenia. - A, H - Mytilus edulis Linnaeus, 1758, oblique (C) and perpendicular (H) views of nacreous layer. • B, C - Leptodea fragilis (Rafinesque, 1820), views of nacreous layer showing shape and size individual platelets. $\bullet$ D, E, F - Pinna nobilis (Linnaeus, 1758), perpendicular (D) and oblique (F) views of nacreous layers; (E) detailed view of nacreous platelets bearing growth lines in form of elongated rectangles. $\bullet \mathrm{G}-$ Quadrula apiculata (Say, 1829), lateral view of nacreous layer. $\bullet$ I - Modiolus barbatus (Linnaeus, 1758), oblique view of nacreous layers. Scale bars: A, B, E-I - $10 \mu \mathrm{m} ; \mathrm{C}, \mathrm{D}-20 \mu \mathrm{m}$.

moderately and strongly developed textural pattern. In other words, the results of texture analysis of the nacreous layer in all studied bivalve species showed that the crystallographic direction [001] of their nacreous platelets form a strongly developed cluster (Fig. 7).

The arrangement of two perpendicular crystallographic directions [100] and [010] (i.e., the crystallographic $a$ - and $b$-axes of aragonite) is variable and depends on species (Figs 4, 6, 8). Because of the arrangement of the [001] directions into a strongly developed cluster, the $a$ - and $b$-axes have to have very similar textural patterns respectively (both of the latter perpendicular directions are located roughly in the same plane being perpendicular to the [001]). For this reason only crystallographic direction [100] (i.e., crystallographic $a$-axis of aragonite) has been plotted (Figs 4, 6, 8). Comparison of Woodcock's C values for the crystallographic directions [100] and [010] clearly show that the strength of the textural pattern is always weaker in the crystallographic direction [100] than for the crystallographic direction [010] (Fig. 6A). The strength of the textural pattern for crystallographic directions [001] and [010] is almost identical, but slightly weaker in the latter direction (Fig. 6A).

Two basic types of arrangement of the crystallographic directions [100] and [010], cluster and girdle-like pattern, were found (Figs 4, 6, 8). Cluster arrangement of the [100] direction was documented in Pinctada radiata (Leach, 1814), Pinna nobilis (Linnaeus, 1758), Amblema plicata (Say, 1817), Quadrula apiculata (Say, 1829), Modiolus barbatus (Linnaeus, 1758), and Brachidontes rostratus (Dunker, 1857). The best arrangement of the [100] directions (i.e. $a$-axes) was found in Pinctada radiata, where the Woodcock's C value reached value of 5.83(1). The lowest Woodcock's $C$ value $[\mathrm{C}=4.33(1)]$ was documented in Modiolus barbatus. Nevertheless, the range of both Woodcock's C and K values place Pinctada radiata, Pinna nobilis, Amblema plicata, Quadrula apiculata, Modiolus barbatus, and Brachidontes rostratus in a group of bivalve species having all the three main crystallographic axes of their nacreous platelets perfectly arranged (all axes have perfect preferred orientation and form strongly developed clusters - Fig. 7). 
Our texture analysis also revealed an occurrence of twinned nacreous platelets having two different orientations (double twinning) according to the usual aragonite twinning on (110). This type of twinning is well known in inorganic as well as organic aragonite (e.g., Bragg 1924, Gauldie \& Nelson 1988, Gauldie 1999). The relative number of twinned platelets (or parts of individual platelets) varies greatly. None were found in the nacreous layer of Pinctada radiata and Modiolus barbatus (Fig. 5B). In Amblema plicata and Pinna nobilis (Fig. 5B) the percentage of twinned platelets was less than 5 percent. The highest percentage of twinned platelets was recorded in Brachidontes rostratus and Quadrula apiculata (Fig. 5B). Values of Woodcock's C and $\mathrm{K}$ ratios in all the abovementioned species were calculated after discarding data on twinned nacreous platelets.

The girdle arrangement for the [100] direction was documented in Nucula nucleus (Linnaeus, 1758), Mytilus californianus (Conrad, 1837), Mytilus galloprovincialis Lamarck, 1819, Mytilus edulis Linnaeus, 1758, and Leptodea fragilis (Rafinesque, 1820). A strongly developed girdle arrangement was found in Nucula nucleus, Mytilus californianus, and Mytilus edulis (sample from the English Channel) where values of Woodcock's C ratio for both crystallographic directions [100] and [010] in nacreous platelets were higher than the critical value $\left(3.5+\mathrm{C}_{95}\right)$. On the other hand, the directions [100] and [010] in Mytilus edulis from Sweden formed a strongly developed girdle with a tendency to develop clusters (Fig. 8A-C). In Mytilus galloprovincialis directions [100] were arranged into a moderately developed girdle, but [010] directions into a strongly developed girdle (Fig. 6J-L). The lowest Woodcock's C value was documented in Leptodea fragilis. Both crystallographic directions [100] and [010] were arranged into a moderately developed girdle $[\mathrm{C}=2.96(3)$ and 3.42(5), respectively], but [001] directions formed a strongly developed cluster (Fig. 8G-I).

\section{Discussion}

SEM study revealed that the microstructure of bivalve nacre is not as uniform as that in gastropods (Figs 1-3). Size distribution as well as thickness of nacreous platelets vary among different bivalve species which confirms earlier observations made by Carter (1900a, b) and published in the hitherto best and most complete summary of our knowledge on bivalve microstructures. Our SEM study also documented differences in shape of the growth lines in Pinna nobilis and Quadrula apiculata which belong to different superorders, Pteriomorphia and Heteroconchia, of the subclass Autolamellibranchiata (Fig. 9). The elongated rectangular shape of growth lines in Pinna nobilis suggest the growth rate of the nacreous platelets strongly depends on growth direction. The ratio between the long and short sides of this rectangle is 1.57(2) which corresponds with the ratio of $a$ - and $b$ - axes of aragonite. In addition, the rectangular growth lines are uniformly oriented in this species (Fig. 3E) which indicates that the direction of maximal growth rate was identical in all plates. The latter direction is parallel to the long axis of the shell in Pinna nobilis and is identical to the $b$-axes of aragonite platelets. Uneven growth of nacreous platelets was reported in Atrina rigida (Lightfoot, 1786) by Addadi et al. (2006) who found elogated hexagon-shaped growth lines on the surface of the nacreous platelets. On the other hand, the regular hexagonshaped growth lines in Quadrula apiculata (Fig. 2E, F) is evidence of an even growth rate of the pseudo-hexagonal nacreous platelets. Analyses of the crystallographic texture of nacre (Figs 4G-L; 8J-L) in Pinna nobilis and Quadrula apiculata however confirmed the same textural pattern of the nacre in the both species - all three main crystallographic axes of their nacreous platelets are perfectly arranged (i.e., all crystallographic axes have the perfect preferred orientation and form strongly developed clusters). A considerable difference in the percentage of twinned nacreous platelets is the only textural feature differing in the above-mentioned species (Fig. 5B).

It should be noted that twinning of calcium carbonate may be influenced by intracrystalline proteins in molluscs. Pokroy et al. (2007) reported their discovery of a formerly unknown twin form in calcite crystals grown from solution to which a mollusc shell-derived $17-\mathrm{kDa}$ protein, Caspartin, was added. This intracrystalline protein was extracted from the calcitic prisms of Pinna nobilis. The crucial role of biological macromolecules on the intensity of twinning in nacreous platelets also seems to be probable. Mukai et al. (2010) recently reported an interesting observation on aragonite twinning in gastropods. The growth front of gastropod nacre forms a "stack-of-coins" structure consisting of pseudo-hexagonal and elliptical aragonite tablets. Mukai et al. (2010) showed that the crystal orientation of each tablet in a stack is almost the same. On the other hand, they found a high density of ( $\left.\begin{array}{lll}1 & 1 & 0\end{array}\right)$ twins in the fibrous aragonite layer formed prior to the construction of the nacreous layer. They concluded that the interlamellar organic sheet might prevent the inheritance of twins, by selecting only a single domain of the twins, through the mineral bridge. Differences in shapes of growth lines as well as in the percentage of twinned platelets may suggest variations in nacre growth mechanism in different phylogenetic lineages of the Class Bivalvia.

Two basic textural patterns of the nacreous platelets were documented in present study - unordered and ordered nacre. The diagnostic character of the first textural pattern is a perfect preferred arrangement of [001] axes and a random arrangement of [100] and [010] axes which form a characteristic girdle-like pattern in stereographic projec- 

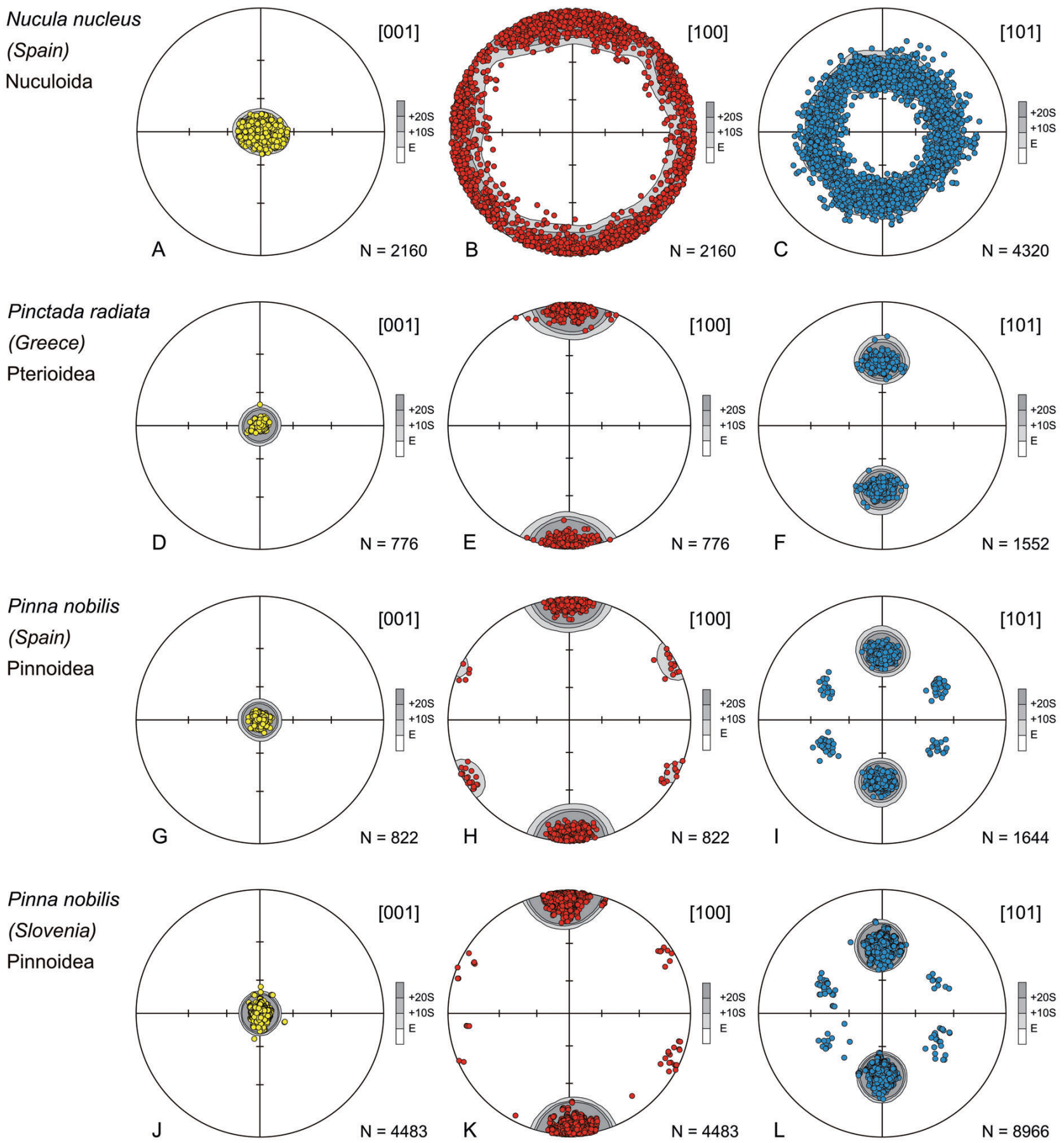

Figure 4. Results of crystallographic texture analysis of nacre in Nucula nucleus (Linnaeus, 1758), Pinctada radiata (Leach, 1814), and Pinna nobilis (Linnaeus, 1758) figured in stereographic projection. • A-C - Nucula nucleus, Mediterranean Sea, Spain. • D-F - Pinctada radiata, Mediterranean Sea, Greece. $\bullet$ G-I - Pinna nobilis, Mediterranean Sea, Spain. $\bullet \mathrm{J}-\mathrm{L}-$ Pinna nobilis, Adriatic Sea, Slovenia. For all projections the direction perpendicular to the page is identical with the direction perpendicular to the inner shell surface, direction from left to right is identical with growth direction of the shell. - A, D, G, J - crystallographic direction [001], B, E, H, K - crystallographic direction [100], C, F, I, L - crystallographic directions [101] and [101]; see text for detailed description.

tion (e.g., Fig. 6G-I). This textural pattern is also referred to as a fibre-like texture. The second textural pattern of the nacre documented in present study is the so-called ordered nacre or single crystal-like pattern. The perfect preferred arrangement of [100], [010], and [001] axes is typical for this pattern. Each group of these axes form a cluster-like pattern in stereographic projection (e.g., Fig. 6A-C). Both textural types were already reported in the Bivalvia (e.g., 

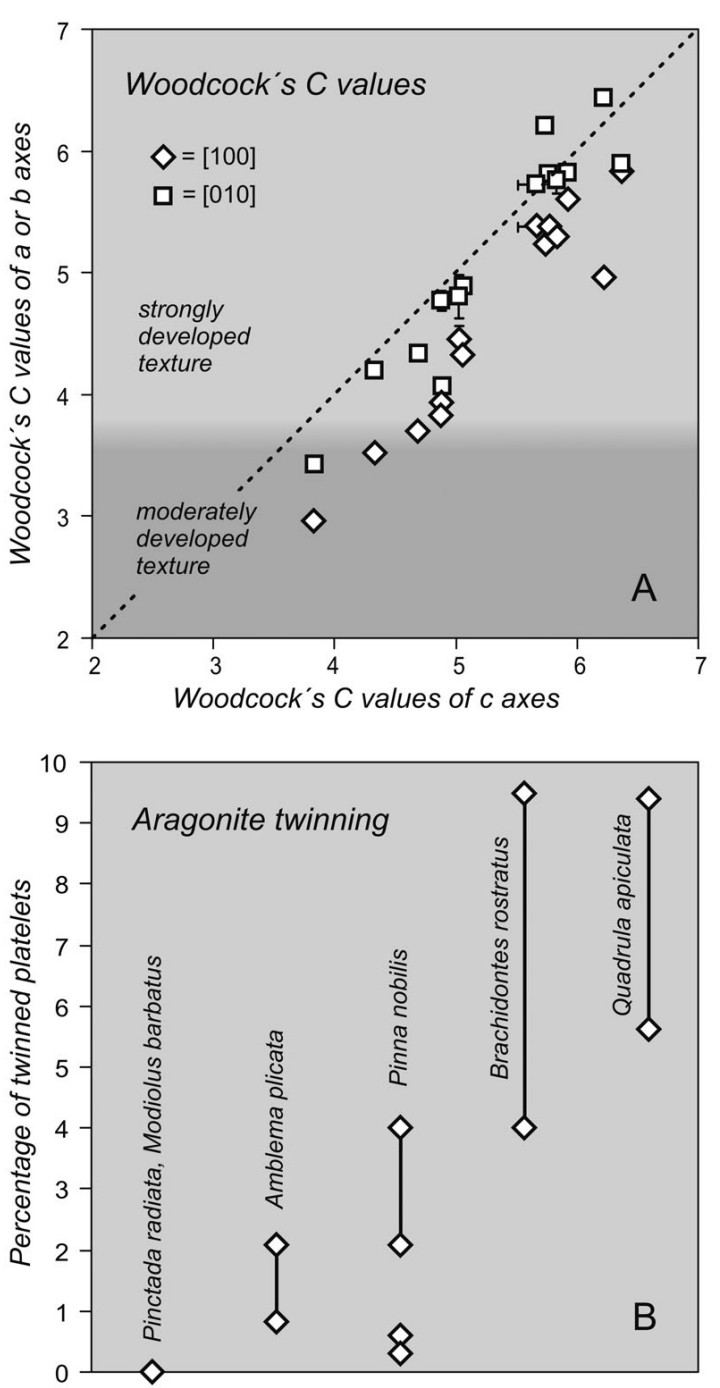

Figure 5. Diagrams showing (A) relationship between Woodcock's C values of all crystallographic axes and (B) percentage of twinned platelets. $\cdot \mathrm{A}$ - note that texture strength of $b$ - and $c$-axes are almost identical but that of $a$-axes is always weaker than that of $b$-axes. $\bullet \mathrm{B}$-percentage of twinned aragonite platelets calculated as the ratio of twinned platelets to total number of platelets measured. Different number of twinned platelets (or parts of individual platelets) for each of the orientations (double twinning) is shown.

Chateigner et al. 2000; Checa \& Rodríguez-Navarro 2000, 2005). Chateigner et al. (2000) analyzed textural pattern of the nacre in twelve bivalve species using X-ray diffraction to determine the orientation distribution of thousands of crystallites (nacreous platelets) in an area 1-3 mm in diam- eter. This method however does not allow analysis of the orientation of individual nacreous platelets, but it gives information on the dominant textural pattern of a relatively very large volume of the selected shell layer. Chateigner et al. (2000) reported that the $c$-axes of nacreous platelets is perpendicular to the inner shell surface (which is in agreement with our data; Figs 4, 6, 8). They also found six maxima for $a$-axes in all studied species. The latter texture was interpreted as a product of double twinned orientation of some platelets or twinning of individual platelets. Chateigner et al. (2000) concluded that all bivalve species involved in their study had the same textural pattern in the nacreous layer (perfect preferred arrangement of [100], [010], and [001] axes). Three of those species, Pinna nobilis, Mytilus californianus, and Mytilus edulis, were analyzed also by us. In the case of the first species our data fits well with the results of Chateigner et al. (2000). Also the high texture strength for all crystallographic directions in Pinna nobilis nacreous platelets, expressed by a high Woodcock's C value (our study) or by high value of $\mathrm{F}^{2}$ (Chateigner et al. 2000) corresponds. Differences occur in the level of twinning which is less than 5 percent in the specimens we studied (Fig. 5B) but 38 percent in specimens studied by Chateigner et al. (2000). However it is difficult to compare these values because there were differences in the methods used. We analyzed an area significantly less than one square millimeter and data were collected only from the nacreous platelets lying on the polished surface of the nacre. In contract, in the method adopted by Chateigner et al. (2000) not only the orientation of nacreous platelets from area 1-3 $\mathrm{mm}$ in diameter were analyzed, but also from subsurface levels. Thus both methods characterize a quite different volume of nacre. A small percentage of twinning was also reported by Checa et al. (2005) in some pterioid bivalves analyzed earlier by Chateigner et al. (2000).

Results of our texture analysis in the species Mytilus californianus and Mytilus edulis differ considerable from data published by Chateigner et al. (2000). The latter authors found, as mentioned above, a perfect preferred arrangement of [100], [010], and [001] axes forming a cluster-like textural pattern in both species with 65 and 52 percent of normalized twinned volume factions, respectively. In addition they documented very weak texture strength in both taxa (i.e., very low value for their $\mathrm{F}^{2}$ ). However our analysis of a much smaller volume of nacreous platelets (those being roughly in the middle of the na-

Figure 6. Results of crystallographic texture analysis of nacre in Modiolus barbatus (Linnaeus, 1758), Brachidontes rostratus (Dunker, 1857), Mytilus californianus (Conrad, 1837), Mytilus galloprovincialis Lamarck, 1819, and Mytilus edulis Linnaeus, 1758, figured in stereographic projection. -A-C-Modiolus barbatus, Adriatic Sea, Slovenia. • D-F-Brachidontes rostratus, NSW, Australia. • G-I - Mytilus californianus, Pacific Ocean, Oregon, U.S.A. - J-L - Mytilus galloprovincialis, Adriatic Sea, Croatia. • M-O - Mytilus edulis, the English Channel, England. For projection details see Fig. 4. - A, D, G, J, M - crystallographic direction [001], B, E, H, K, N-crystallographic direction [100], C, F, I, K, O - crystallographic directions [101] and [101]. 

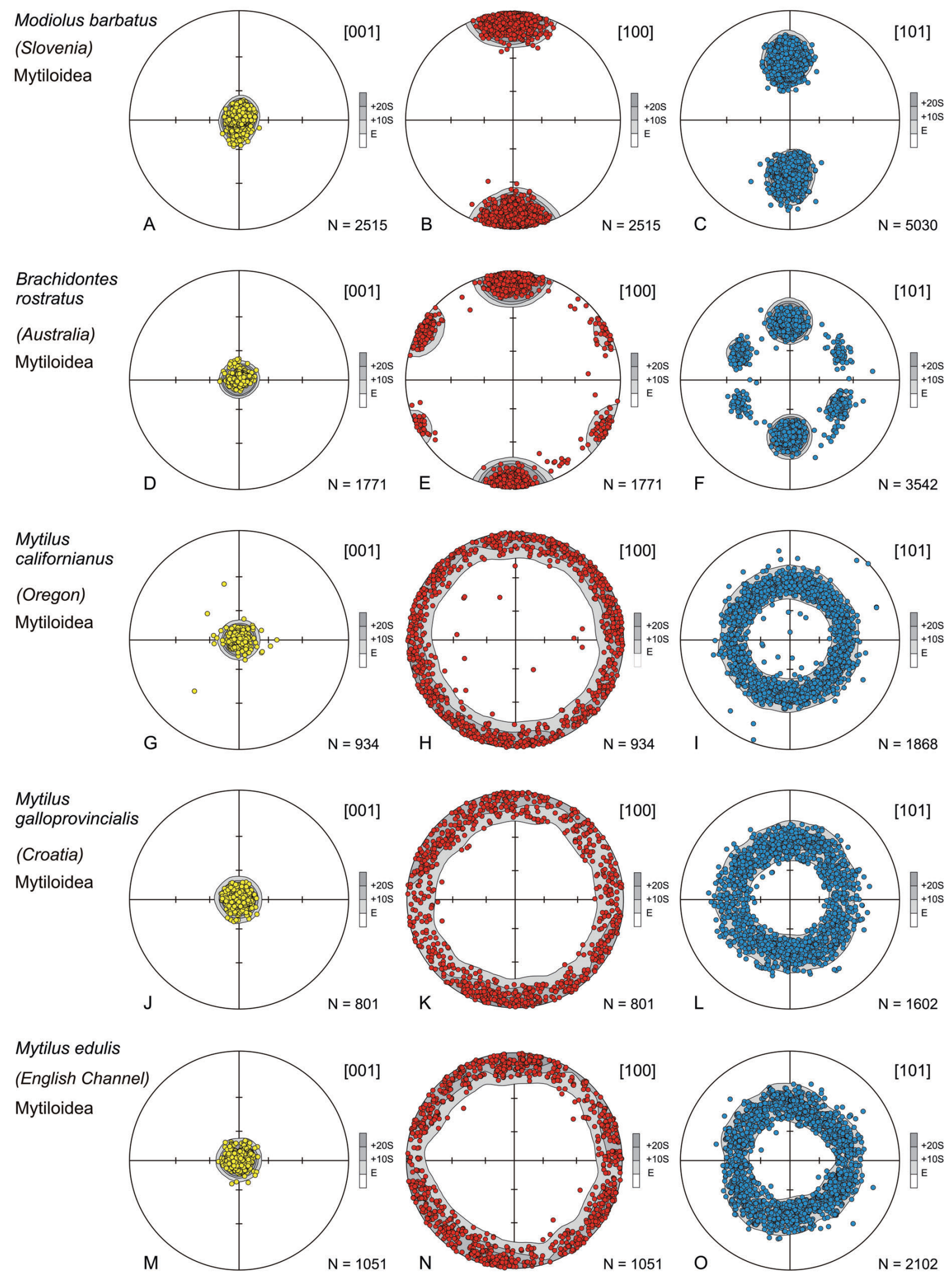

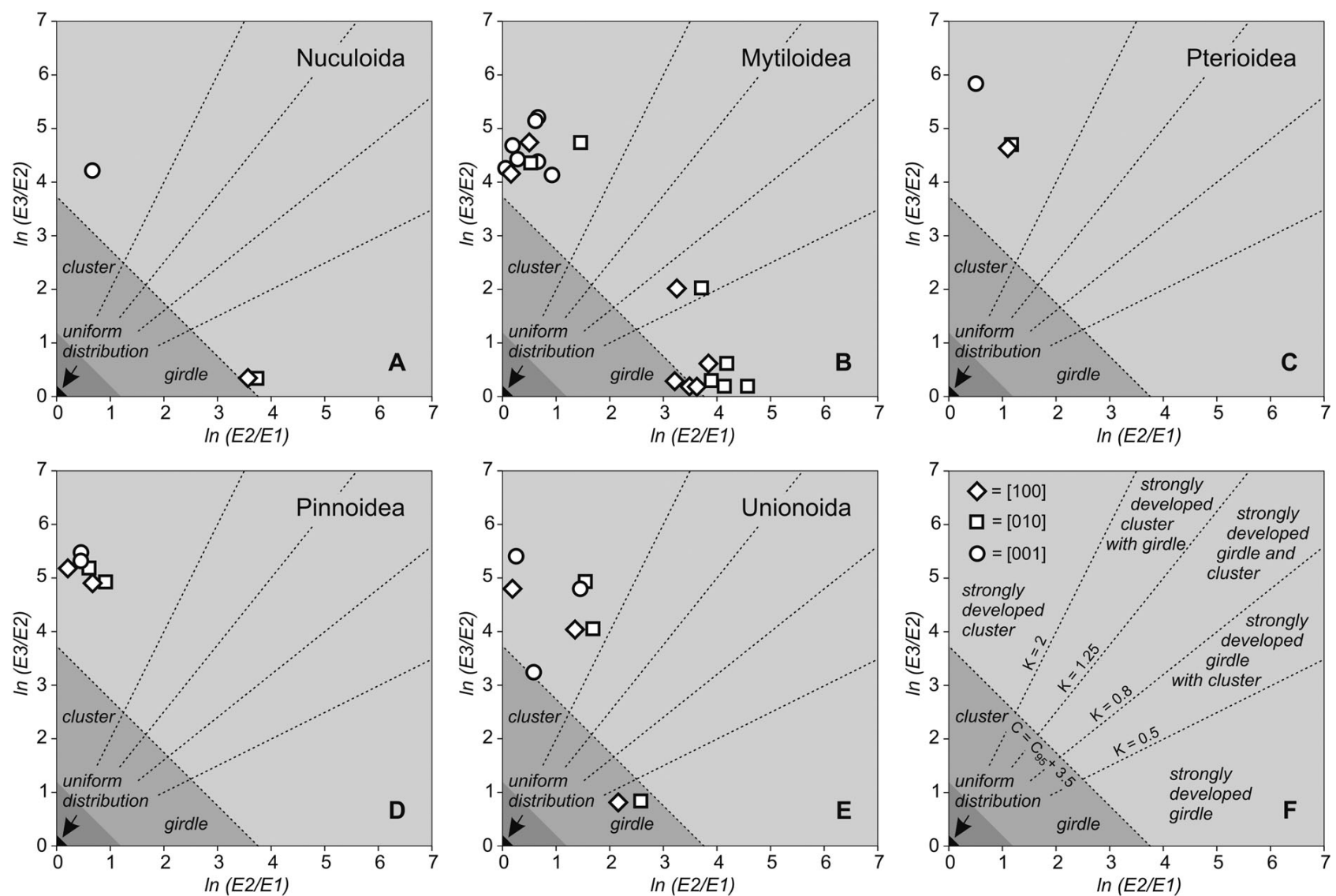

Figure 7. Calculated values of Woodcock's ratios plotted on a modified Flinn diagram for (A) Nuculoida, (B) Mytiloidea, (C) Pterioidea, (D) Pinnoidea, and (E) Unionoida. Explanation of the modified Flinn diagram is given in $\mathrm{F}$.

creous layer) in the same species revealed a quite different textural pattern - random arrangement of [100] and [010] axes forming a girdle-like textural pattern (unordered nacre; Fig. 6). This difference cannot be explained only by the fact that the two methods analyzed incommensurable volumes of nacre and it therefore requires further study. A girdle-like arrangement in the [100] direction was also documented in Nucula nucleus, Mytilus galloprovincialis, and Leptodea fragilis. Textural patterns in these species could not be compared with published data because according to our knowledge, the texture of the nacre of those species was not analyzed previously.

In 2000 and 2005 Checa \& Rodríguez-Navarro reported interesting results on changes of texture patterns in the shell layer during bivalve ontogeny. In 2000 they published a study on shell microstructure and texture in five unionid bivalves the shells of which are characterized by an outer aragonitic prismatic layer and an inner nacreous layer. The prisms of the outer shell layer are composed of single-crystal fibres radiating from spheruliths. Checa \& Rodríguez-Navarro (2000) presented a new model describing competition between prisms leading to the selection of bigger, evenly sized prisms. They showed that during prism growth, fibres become progressively orientated with their three crystallographic axes aligned, which is a result of geometric constraints and space limitations. According to Checa \& Rodríguez-Navarro (2000) there is no selection of crystal orientation in the nacreous layer and, as a result, the preferential orientation of crystals deteriorates. In contrast to the prismatic layer crystals which later exhibit better organization, Checa \& Rodríguez-Navarro (2000) showed that nacreous platelets become less organized as the nacreous layer becomes thicker (see their fig. 4c). They interpreted deterioration of crystal orientation as a result of the accumulation of errors as the epitaxial growth is suppressed by thick or continuous organic coats on some nacre crystals. The new model proposed by Checa \& Rodríguez-Navarro (2000), based partly on observations made by Ubukata (1994), is in contrast to earlier published models (e.g., Wise 1970; Wada 1972; Weiner \& Traub 1980, 1984; Mutvei 1980) because it suggests that the microstructural and textural arrangement of the unionid shell is, to a large extent, self-organized with the main constraints being crystallographic and geometrical laws. Weiner \& Traub $(1980,1984)$ suggested that crystal orientation is imposed by epitaxial nucleation on the organic matrix sur- 

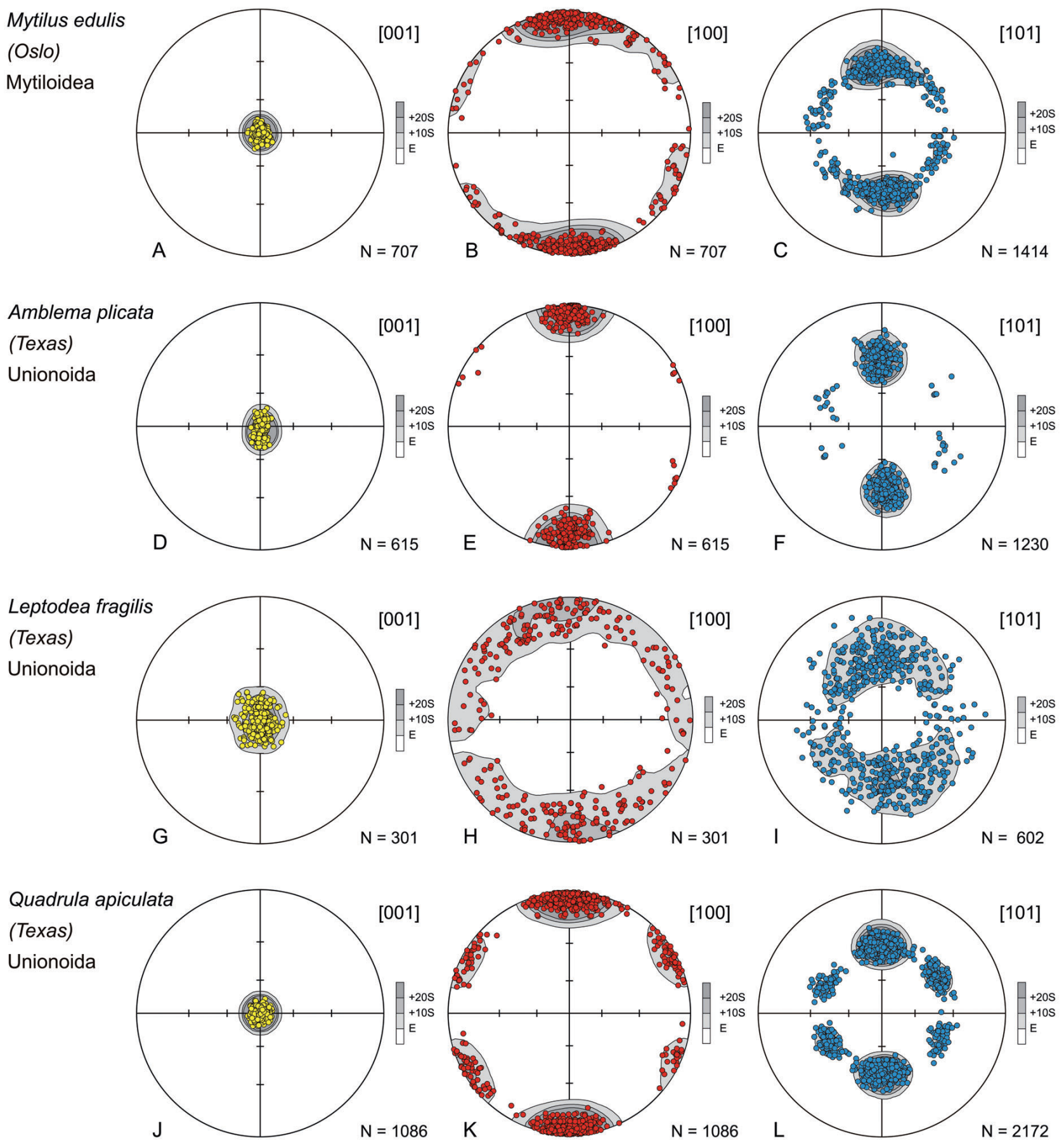

Figure 8. Results of crystallographic texture analysis of nacre in Mytilus edulis Linnaeus, 1758, Amblema plicata (Say, 1817), Leptodea fragilis (Rafinesque, 1820), and Quadrula apiculata (Say, 1829), figured in stereographic projection. - A-C - Mytilus edulis, North Sea, Sweden. - D-F - Amblema plicata, NW Texas. • G-I - Leptodea fragilis, NW Texas. • J-L - Quadrula apiculata, NW Texas. For projection details see Fig. 4. - A, D, G, J - crystallographic direction [001], B, E, H, K - crystallographic direction [100], C, F, I, L - crystallographic directions [101] and [101].

face. The latter model however does not explain the textural changes (i.e., changes at the level of crystal axes arrangement) observed by Checa \& Rodríguez-Navarro (2000). Later Checa \& Rodríguez-Navarro (2005) studied in detail the ontogeny of the nacreous layer in some pterioid bivalves and proposed a new model describing self-organization of the nacre. They showed that early crystals of nacre nucleated on the organic membrane usually covering the outer prismatic layer. Checa \& Rodríguez-Navarro (2005) pointed out that the first nacreous 
platelets are formed by polycrystalline aggregates of various shapes and have their $c$-axes well organized and perpendicular to the inner shell surface, but their $a$ - and $b$-axis showed considerable variation in arrangement. The increasing preferred orientation of nacreous platelets can be explained by a competition model between the nacreous plates within the growing lamellae. The model proposed by Checa \& Rodríguez-Navarro (2005) was based on the interpretation of data derived from X-ray texture diffractometry having relatively low space resolution. Later Checa et al. (2006) tested this model using a method with much better space resolution, i.e. electron back scatter diffraction analysis. They analyzed nacre of several species of the bivalve family Pteriidae. Their new data revealed that in Pteria hirundo (Linnaeus, 1758) and Pinctada martensii Dunker, 1872, the nacreous platelets become well organized (i.e., mean angle between the $b$-axis and the growth direction is about 10 degrees or less, thus all axes of nacreous platelets are forming clusters as is typical for a single crystal-like ordered nacre) during growth of only about 20 to 30 nacreous lamellae (see fig. 2 in Checa et al. 2006). Thus when the thickness of the nacreous layer covering the prismatic layer becomes about 10 to $15 \mu \mathrm{m}$, the nacreous platelets have a single crystal-like texture. Checa et al. (2006) developed a theoretical model which simulates competition between rhombic plates at the lamellar growth front as well as epitaxial growth of crystals onto those of the preceding lamella. According to their model, the rate of final stabilization of $b$-axis alignment (i.e., state when $a$ - and $b$-axes of single crystal-like ordered nacre form clusters having the same size during the next phase of growth) depends on parameters characterizing the geometry of nacre growth fronts (diffuse versus linear growth fronts). Theoretical simulation showed that in the case of diffuse growth fronts, which is a relatively common case in bivalve nacre, selection is weak and a good alignment is produced only after a large number (hundreds) of layers have accumulated. However Checa et al. (2006) noted that selection intensity is also dependent on the extent of the growing lamella.

Taken together, the random arrangement of [100] and [010] axes in nacreous platelets forming a girdle-like textural pattern (unordered nacre) should be restricted to a very thin part of the nacreous layers adjacent to the prismatic layer. These results fit with measurements in Pteria hirundo (Linnaeus, 1758) and Pinctada martensii Dunker, 1872, where the nacreous platelets become well organized during growth to only about 20 to 30 nacreous lamellae (about 10 to $15 \mu \mathrm{m}$ in the direction perpendicular to the boundary of prismatic and nacreous layers). The model proposed by Checa et al. (2006), as well as their data, lead to the concept that only a very thin sublayer of the nacreous layer close to boundary of the prismatic and nacreous layers has a girdle-like textural pattern (unordered nacre). The $a$-and $b$-axes of the nacreous platelets farther from this boundary become gradually arranged into one cluster and the texture of the nacre changes into a single crystal-like texture. Thus the vast majority of nacreous layer platelets in bivalves have the latter texture pattern. This is a reason why texture analyses using X-ray texture diffractometry revealed only the single crystal-like ordered nacre (e.g., Chateigner et al. 2000). In this context, the results of our texture analyses have been somewhat surprising. We analyzed a relatively small area of nacre in a plane parallel to the boundary of the prismatic and nacreous layers and cutting through the nacreous layer roughly in the centre of its maximum thickness. Thus our analyzed samples involved nacreous platelets which are at least many tens or a few hundred microns from the boundary of the prismatic and nacreous layers. At this distance, the single crystal-like arrangement of nacreous platelets was expected. However, a girdle-like arrangement of the [100] directions was documented in some species (Figs 4, 6, 8). On the other hand, the single crystal-like arrangement of the [100] directions was found in some species with a relatively thin nacreous layer (e.g., Pinna nobilis; maximum dimension of shells of analyzed specimens from both localities was lesser than $20 \mathrm{~cm}$ ). These data suggest that rate of alignment of $a$ - and $b$-axes from girdle-like to a single crystal-like texture considerably differs in the species analyzed. As shown by Checa et al. (2006) the nature of growth fronts may considerably change the rate of alignment of the [100] and [010] directions. If the character of the growth fronts is the only factor influencing selection intensity which drives the rate of alignment is a topic for future research.

Dauphin et al. (2008) studied in detail the nacre-prisms transition in shells of Pinctada margaritifera and showed that this boundary is not an abrupt transition, but there exists a distinct fibrous layer with clear topographic structures and evidence of growth lines. They described in detail the biomineralization process involving changes in the chemical and biochemical composition in the last growth increments of the calcite prisms, subsequent formation of the fibrous layer, and development of regular platelets in the nacreous layer. Later Rousseau et al. (2009) reported a growth-ring structure, rich in organic materials, surrounding each growing nacre tablet during formation of sheet nacre in the same species of the genus Pinctada, in P. margaritifera, as was studied earlier by Dauphin et al. (2008). Rousseau et al. (2009) documented the pivotal role of this growth-ring structure which disappears as the nacre tablets grow laterally and collide with adjacent tablets. Lateral, symmetric growth of individual tablets is mediated by an organic rich growth-ring, in which aragonite crystallizes from its amorphous precursors.

Saruwatari et al. (2009) studied in detail the growth front of the nacreous layer, which lies just above the outer prismatic layer in another species of pearl oyster, Pinctada 


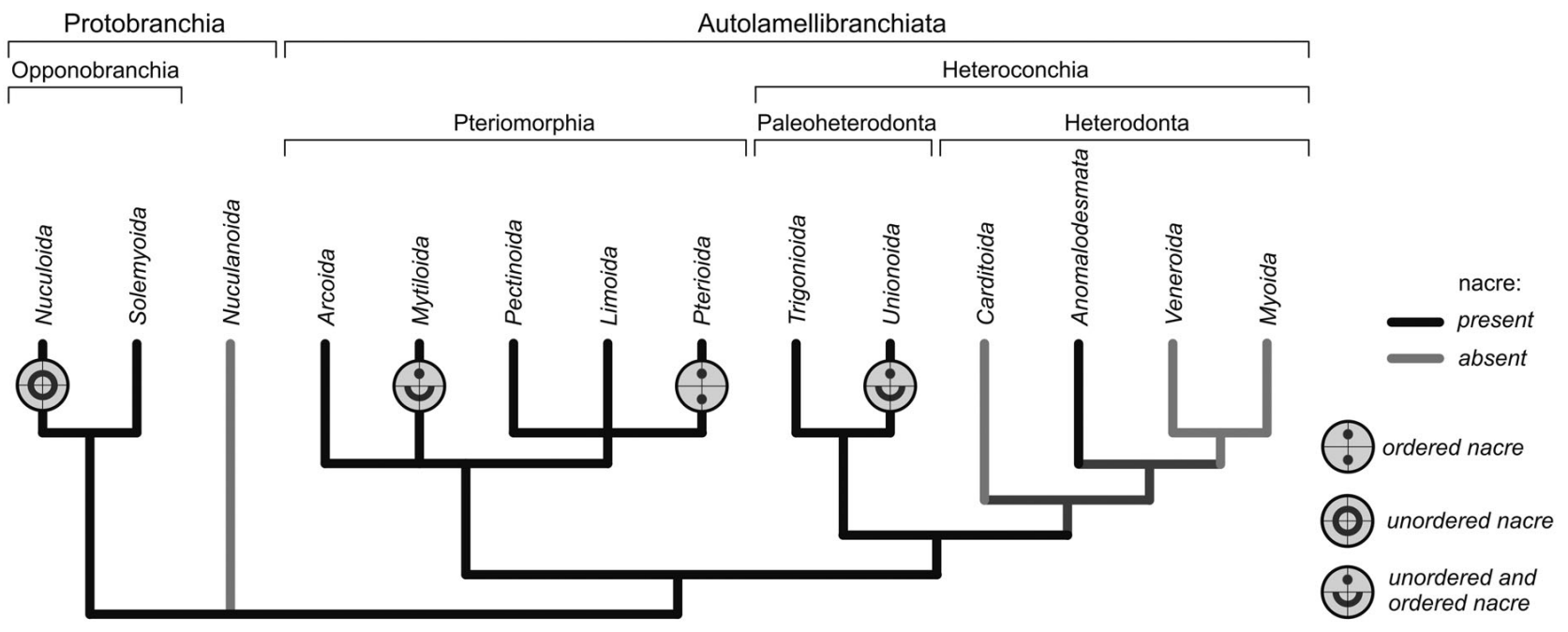

Figure 9. Diagram showing phylogenetic relationship of bivalve groups, modified from Bieler \& Mikkelsen (2006), Giribet (2008) and Bieler et al. (2010). Black lines indicate bivalve lineages developing nacreous layer. Type of crystallographic texture pattern documented by present study is also shown.

fucata. They found that nano-sized aragonite crystals nucleate with a random crystallographic orientation inside the dimples on the surface of the organic matrix which covers the outer prismatic columns. These horn-like aragonite crystals enlarge from the bottom to the top of upper surface to form hemispheric domes which grow concentrically and form the initial nacreous layer. Saruwatari et al. (2009) also showed that the horn-like aragonite crystals, having a $c$-axis perpendicular to the surface, grow until they are covered by new organic sheets which interrupt the crystal growth. Further crystal growth along the shell thickness is attained via mineral bridges through discontinuity or holes in the organic sheets.

All the above-mentioned data indicate that crystal growth of nacreous platelets at the growth front result not only from inorganic process such as geometrical selection and mineral bridges but also biotic processes. The many new observations acquired during the last two decades have produced good evidence that organic molecules control not only selection of the calcium carbonate polymorph but also the shape and orientation of nacreous platelets (see Marin \& Luquet 2004, Marin et al. 2008, and Suzuki et al. 2009 , for details and references). Our data on crystallographic texture suggest that the rate of self-organization of nacre and percentage of twinning in bivalves is relatively variable and the process is probably not only controlled by crystallographic constraints but also by complex molecular mechanisms. Nevertheless at present our data on crystallographic texture of nacre with a high space resolution (i.e., analyses of orientation of individual nacreous platelets) are available for only several bivalve species. Detailed data on the distribution of textural patterns in nacre over the whole shell as well as data on changes in textural patterns of nacre and intensity of twinning during shell ontogeny are miss- ing. Our data also revealed that in future the crystallographic texture data must be connected with more precise geometrical information regarding the analyzed area in terms of position on the shell but also with respect to boundaries of individual shell layers. To date, there has been no study comparing the crystallographic texture data of left and right valves of bivalve shell.

Nacre has been considered to be a primitive shell layer in Bivalvia because it occurs in the vast majority of basal groups (Fig. 9). Results of our crystallographic texture analysis suggest that ordered nacre occurs in more derived bivalve groups which could suggest that unordered nacre or nacre which becomes slowly ordered during ontogeny may represent a primary state in the Bivalvia (Fig. 9). However at present there are not enough data on nacre to test this hypothesis. Cartwright \& Checa (2007) noted that bivalve nacre is possibly an energetically high-cost material and because of that "it is seen in the fossil record to be gradually losing 'market share' in molluscs in favour of cheaper, but less high-performance materials". However such a conclusion is probably preliminary because our knowledge of shell mineralogy in the Paleozoic Bivalvia is very limited (see Carter 1990). Amongst the Early Paleozoic bivalves one may find groups even at order level with data missing on their shell microstructure. Members of the superorder Nepiomorphia Kř́žz, 2007, which often formed one of the dominant components of Early Paleozoic bivalve communities (e.g., Kříž 2007, 2008a, b), may be mentioned as a good example. In addition, even in bivalve groups with known shell mineralogy, in geologically younger taxa, there is some doubt whether their Early Paleozoic ancestors had the same shell mineralogy. All hitherto known Early Paleozoic bivalve species are based on fossil material having recrystallized shells or even shell imprints (e.g., 
Kř́ž \& Steinová 2009). The number of Late Paleozoic bivalve species with originally preserved shell is also limited (see Carter 1990). Estimation of the ratio between bivalves having and those lacking a nacreous layer for the first two fifths ( $c c a 200$ million years) of bivalve evolution is thus uncertain although a decrease in this ratio during their post-Paleozoic evolution seems to be well documented (see fig. 8 in Cartwright \& Checa 2007). However the reduction in this ratio could be caused by quite different reasons than the energetic cost of nacre formation. Also in the Class Gastropoda a decrease in the proportion of nacrebearing taxa during evolution seems to be well documented since Devonian time. However the main reason for an increasing proportion of nacre-lacking gastropods (like members of the orders Neritimorpha, Caenogastropoda and Heterobranchia) is probably not the energetic cost of nacre formation but development of a new ontogenetic strategy. The origin of planktotrophy during the Devonian which gave them the ability to use a completely new food source and resulted in a much higher dispersal potential (Nützel \& Frýda 2004, Klug et al. 2010, but see also Nützel et al. 2006).

Taken together, the present lack of paleontological data as well as data on the crystallographic texture in different bivalve groups does not allow testing of the models describing the phylogenetic relationship of bivalve groups which has been inferred from different types of molecular data.

\section{Nacre - derived or primitive microstructure: a paleontological view}

The question as to whether nacre represents a shared microstructure among conchiferan molluscan classes (with the exception of Scaphopoda) or apomorphy of individual classes is still a matter of debate. Nacre occurs in only four of the eight molluscan classes, in Cephalopoda, Gastropoda, Bivalvia, and Monoplacophora. Co-occurrence of nacre has often been interpreted as evidence for its presence in the ancestors of these groups. However, direct evidence of the existence of nacre in the oldest molluscs is still missing. In some Cambrian molluscs imprints or shell replicates have been documented which resemble nacre in its microstructure and were interpreted as evidence of its presence (Runnegar 1985, Kouchinsky 2000, Feng \& Sun 2003, Parkhaev 2008). However the latter interpretations are somewhat questionable. Another indirect and so questionable evidence for the ancient origin of nacre is inferred from the occurrence of nacreous platelets in members of the basal phylogenetic lineages. Columnar nacre forms the main shell microstructure in all shell-bearing cephalopods. The majority of cephalopod lineages originated in the latest Cambrian and Early Ordovician (see references in Nishiguchi \& Mapes 2008) which strongly supports its existence in cephalopod ancestors. Similarly in the Class Bivalvia, nacre is present in basal bivalve lineages (Opponobranchia and basal Autolamellibranchia; see Carter 1990a, b; Giribet 2008; fig. 9) which also originated in the latest Cambrian and Early Ordovician. Thus bivalve sheet nacre was also probably present in the oldest bivalves and their ancestors.

A more complicated situation occurs in the Class Gastropoda. Columnar nacre is present in only one phylogenetic lineage, the Archaeogastropoda (sensu Bandel 1982, 1997), which includes also the Vetigastropoda (Aktipis et al. 2008). Gastropod nacre seems to have remained unchanged for at least 220 million years (Frýda et al. 2009). However, nacre is not present in patellogastropods (MacClintock 1968, Bandel \& Geldmacher 1996, Fuchigami \& Sasaki 2005) which have been interpreted as the first gastropod offshoot (Ponder \& Lindberg 1997, 2008; see also discussion in Frýda et al. 2009b). In addition not all vetigastropods have nacre (Bandel \& Geldmacher 1996 Geiger et al. 2008). Whether the patellogastropods and nacre-lacking vetigastropods lost the ability to produce a nacreous layer during their long evolution or if their ancestors never developed it, is still unknown. On the other hand the basal position of patellogastropods is not yet well supported by paleontological data (Hedegaard et al. 1997, Frýda et al. 2008). The oldest direct evidence of gastropod nacre is of Carboniferrous age (e.g., Batten 1972, Bandel et al. 2002) and recrystallized relicts of a nacreous layer was documented in a few Devonian gastropods (Carter 1990a, b). Nevertheless there is indirect evidence for the occurrence of a nacreous layer in pre-Devonian gastropods. Even though classification of the Paleozoic gastropods is still somewhat unstable (compare Bandel 1997, Wagner 1999, Bouchet et al. 2005) there are some gastropod groups such as the Macluritoidea (see Rohr et al. 1992, Rohr \& Gubanov 1997, Frýda \& Rohr 2006 for references) and Porcellioidea (Bandel 1993; Frýda \& Blodgett 1998, 2004) which may be easily recognized by the unusual features of their characteristic shell morphologies. Presence of nacre (Kiel \& Frýda 2004) and an archeogastropod-type protoconch (Bandel 1993) in the latter group are undoubtedly evidence for its placement amongst nacre-bearing archaeogastropods. The Silurian age of the oldest porcellioidean gastropods (Frýda 1997 and unpublished data) and their considerable morphological disparity evidence their origin from other archaeogastropods in the Early Silurian or Ordovician. If nacre was not developed in porcellioideans independently from other archaeogastropods then at least an Ordovician origin of gastropod nacre seems to be probable. Interpretation of the origin of a nacreous layer in the Monoplacophora is the most complicated. Recent studies by Checa et al. (2009) revealed that sheet nacre occurs only in some living monoplacophorans. In addition, the relationship between living and fossil monoplacophorans of Paleozoic age is somewhat problematic. 
The origin of nacreous microstructure in the Cambrian seems thus to be highly probable even though there is no direct evidence for it. The crucial question however is whether it represents a homologous shell microstructure or if originated independently in different molluscan classes. Differences in its microstructure and crystallographic texture among different molluscan classes seems to suggest its independent origin. Such a scenario was independently inferred from molecular data. Some recent molecular studies suggest that nacre is a shell structure, which is not homologous between molluscan classes and originated independently (Marie et al. 2009, Jackson et al. 2009). On the other hand, results of other molecular studies indicate that some molecular processes of biomineralization are very old (see discussion in Marin et al. 2008). The question is how much the genome driving nacre formation was changed in individual phylogenetic lineages during an evolution of more than 500 million years. Another question is what is the exact role of molecules, which have been used for the analyses of phylogenetic distances between individual molluscan classes, in the biomineralization processes. Taken altogether, there is too much missing data on the nature of nacre in many living and extinct molluscan groups as well as scant knowledge of some parts of the biomineralization processes, that the question if nacre is derived or a shared shell microstructure among molluscan classes must still remain open.

\section{Conclusions}

Analysis of the crystallographic texture of nacre in eleven bivalve species belonging to the superorders Opponobranchia, Pteriomorpha, and Paleoheterodonta, revealed its considerable variability. Present analysis confirmed uniform orientation of crystallographic $c$-axes of aragonite platelets in all the studied species, but variable arrangement of $a$ - and $b$-axes (Figs 4, 6, 8). New data suggest that the rate of alignment of $a$ - and $b$-axes from girdle-like (unordered nacre) to a single crystal-like texture (ordered nacre) considerably differs among the analyzed species. Numerical evaluation of the data obtained from bivalve species with ordered nacre also revealed a systematic difference in texture strength among the main crystallographic axes of aragonite platelets. The texture strength of $a$-axes (direction parallel with growth lines) is always weaker than that of $b$ - and $c$-axes (Fig. 5A). Difference in the shape of growth lines found on the surface of nacreous platelets was documented in Pinna nobilis and Quadrula apiculata which belong to different superorders, Pteriomorphia and Heteroconchia, from the subclass Autolamellibranchiata (Figs 2, 3). Our texture analysis also revealed distinct differences in percentage of twinned nacreous platelets among the studied species. The highest percentage of twinned pla- telets was recorded in Brachidontes rostratus and Quadrula apiculata where it reached a value of 10 percent (Fig. 5B). Observed differences in the shape of the growth lines, in twinning percentage as well as in the rate of alignment of $a$ - and $b$-axes suggest variations in nacre growth processes in individual phylogenetic lineages of the Class Bivalvia. These facts may imply not only evolutionary changes in microstructure and crystallographic texture of nacre but also in molecular mechanisms driving its production during the long history of molluscan evolution.

Evolution and the origin of a nacreous shell layer are still somewhat puzzling. Its origin in the Cambrian seems to be highly probable even though there is no clear evidence for it from a paleontological point of view. Also the crucial question as to whether nacre represents a shell microstructure being homologous in all conchiferan molluscs or if it originated independently in different molluscan classes is still unsolved. Too much missing data on the nature of nacre (crystallographic texture) in the majority of living and extinct molluscan groups as well as poor knowledge of some parts of the biomineralization processes leave this question unanswered.

\section{Acknowledgements}

This work is partly based on Magdalena Klicnarová's Masters thesis (Faculty of Environmental Sciences, Czech University of Life Sciences Prague) and was supported by grants from the Grant Agency of the Czech Republic (205/08/0062), Project No. 0002700604 (Výzkumný záměr MZE) and the Czech-American Cooperation Program (Kontakt ME08011). The authors thank Tomáš Frýda (Prague) for his software package Škeble, and Robert B. Blodgett (Anchorage) and Štěpán Manda (Prague) for their helpful reviews. The linguistic help of Robert B. Blodgett is also gratefully acknowledged.

\section{References}

Addadi, L., Joester, D., Nudelman, F. \& Weiner, S. 2006. Mollusk Shell Formation: A Source of New Concepts for Understanding Biomineralization Processes. Chemistry - A European Journal 12, 980-987. DOI 10.1002/chem.200500980

Aktipis, S.W., Giribet, G., Lindberg, D.R. \& Ponder, W.F. 2008. Gastropoda - an overview and analysis, 201-237. In Ponder, W. \& LindBerg, D.L. (eds) Phylogeny and Evolution of the Mollusca. 488 pp. University of California Press, Berkeley and Los Angeles, California.

BANDEL, K. 1982. Morphologie und Bildung der frühontogenetischen Gehäuse bei conchiferen Mollusken. Fazies 7, 1-198.

BANDEL, K. 1993. Evolutionary history of sinistral archaeogastropods with and without slit (Cirroidea, Vetigastropoda). Freiberger Forschungshefte, Paläontologie C450, 41-82.

BANDEL, K. 1997. Higher classification and pattern of evolution of the Gastropoda. Courier Forschungsinstitut Senckenberg 201, 57-81. 
BANDEL, K. \& GeLDMACHER, W. 1996. The structure of the shell of Patella crenata connected with suggestions to the classification and evolution of the Archaeogastropoda. Freiberger Forschungsheft C 464, 1-71.

BANDEL, K., NÜTZEL, A. \& Y ANCEY, T.E. 2002. Larval shells and shell microstructures of exceptionally well-preserved Late Carboniferous gastropods from the Buckhorn Asphalt Deposit (Oklahoma, USA). Senckenbergiana lethaea 82(2), 639-689.

Batten, R.L. 1972. The ultrastructure of five common Pennsylvanian pleurotomarian gastropod species of Eastern United States. American Museum Novitates 2501, 1-34.

Bertoldi, K., Bigoni, D. \& Drugan, W.J. 2008. Nacre: An orthotropic and bimodular elastic material. Composites Science and Technology 68, 1363-1375. DOI 10.1016/j.compscitech.2007.11.016

Beurlen, K. 1944. Beiträge zur Stammesgeschichte der Muscheln. München Akademie Sitzungsberichte 11, 113-131.

Bieler, R. \& MikKesen, P. 2006. Bivalvia - a look at the branches. Zoological Journal of the Linnean Society 148(3), 223-235. DOI 10.1111/j.1096-3642.2006.00255.x

Bieler, R., CARTER, J.G. \& CoAn, E.V. 2010. Classification of bivalve families, 113-133. In Bouchet, P. \& RocroI, J.-P. Nomenclator of bivalve families. Malacologia 52(2), 1-184.

Bouchet, P. \& Rocroi, J.-P. 2010. Nomenclator of bivalve families with a classification of bivalve families by R. Bieler, J.G. Carter \& E.V. Coan. Malacologia 52(2), 1-184. DOI 10.4002/040.052.0201

Bouchet, P., Rocroi, J.-P., FrÝda, J., Hausdorf, B., Ponder, W., VAlDES, A. \& WARÉN, A. 2005. Classification and nomenclator of gastropod families. Malacologia 47(1-2), 1-368.

BraGG, W.L. 1924. The structure of aragonite. Proceedings of the Royal Society of London, Series A105, 16-37. DOI 10.1098/rspa.1924.0002

CARTER, J.G. 1990a. Evolutionary significance of shell microstructure in the Palaeotaxodonta, Pteriomorphia and isofilibranchia (Bivalvia: Mollusca), 136-296. In CARTER, J.G. (ed.) Skeletal Biomineralisation: Patterns, Processes and evolutionary trends. Vol. II. Atlas and Index. 832 pp. Van Nostrand Reinhold, New York.

CARTER, J.G. 1990b. Shell microstructural data for the Bivalvia, 297-412. In CARTER, J.G. (ed.) Skeletal Biomineralisation: Patterns, Processes and evolutionary trends. Vol. II. Atlas and Index. 832 pp. Van Nostrand Reinhold, New York.

Cartwright, J.H.E. \& CheCA, A.G. 2007. The dynamics of nacre self-assembly. Journal of the Royal Society Interface 4, 491-504. DOI 10.1098/rsif.2006.0188

Chateigner, D., Hedegaard, C. \& Wenk, H.-R. 2000. Mollusc shell microstructures and crystallographic textures. Journal of Structural Geology 22, 1723-1735. DOI 10.1016/S0191-8141(00)00088-2

Chateigner, D., Ouhenia, S., Krauss, C., Belkhir, M. \& MoRALES, M. 2010. Structural distortion of biogenic aragonite in strongly textured mollusc shell layers. Nuclear Instruments and Methods in Physics Research B 268, 341-345. DOI 10.1016/j.nimb.2009.07.007

Checa, A.G., Окамото, T. \& RamíRez, J. 2006. Organization pattern of nacre in Pteriidae (Bivalvia: Mollusca) explained by crystal competition. Proceedings of the Royal Society B 273, 1329-1337. DOI 10.1098/rspb.2005.3460

Checa, A.G., Ramírez-Rico, J., González-Segura, A. \& SÁNCHEZ-NAVAS, A. 2008. Nacre and false nacre (foliated aragon- ite) in extant monoplacophorans (= Tryblidiida: Mollusca). Naturwissenschaften, 111-122.

DOI 10.1007/s00114-008-0461-1

Checa, A.G. \& Rodríguez-Navarro, A.B. 2000. Geometrical and crystallographic constraints determine the self-organization of shell microstructures in Unionidae (Bivalvia: Mollusca). Proceedings of the Royal Society of London, Series $B$ 268, 771-778. DOI 10.1098/rspb.2000.1415

CHeca, A.G. \& Rodríguez-NavarRo, A.B. 2005. Self-organisation of nacre in the shells of Pterioida (Bivalvia: Mollusca). Biomaterials 26, 1071-1079.

DOI 10.1016/j.biomaterials.2004.04.007

ConRad, T.A. 1837. Descriptions of new marine shells, from Upper California. Journal of the Academy of Natural Sciences of Philadelphia 7, 227-268.

Cox, L.R. 1960. Thoughts on the classification of the Bivalvia. Proceedings of the Malacological Society of London 34, 60-80.

DALL, W.H. 1889. On the hinge of pelecypods and its development, with an attempt toward a better subdivision of the group. American Journal of Science, Ser. 3, 38(228), 445-462.

Dauphin, Y., Ball, A.D., Cotte, M., Cuif, J.-P., Мeibom, A., Salomé, M., Susini, J. \& Williams, C.T. 2008. A microstructural, mineralogical, and chemical study of the nacre-prisms boundary in the shells of Pinctada margaritifera (Mollusca, Bivalvia). Analytical and Bioanalytical Chemistry 390, 1659-1669. DOI 10.1007/s00216-008-1860-z

Denkena, B., Koehler, J. \& Moral, A. 2010. Ductile and brittle material removal mechanisms in natural nacre - A model for novel implant materials. Journal of Materials Processing Technology 210, 1827-1837. DOI 10.1016/j.jmatprotec.2010.06.014

DunkeR, W. 1857. Mytilacea nova collectionis Cumingianae. Proceedings of the Zoological Society of London 24, 358-366.

DunKER, W. 1872. Die Gattung Avicula in Abbildungennach der Natur mit Beschreibungen. In Küster, H.C. (ed.) Systematisches Conchylien-Cabinet von Martini und Chemnitz, vol. 7. Bauer \& Raspe, Nürnberg.

Falini, G., Shira Albeck, S., Weiner, S. \& Addadi, L. 1996. Control of Aragonite or Calcite Polymorphism by Mollusk Shell Macromolecules. Science 271(5245), 67-69. DOI 10.1126/science.271.5245.67

FEnG, W. \& Sun, W. 2003. Phosphate replicated and replaced microstructure of molluscan shells from the earliest Cambrian of China. Acta Palaeontologica Polonica 48(1), 21-30.

FérussaC, A.E.J.P.J.F. D'AudEBARD DE 1822. Tableaux systématiques des animaux mollusques classés en familles naturelles, dans lesquels on a établi la concordance de tous les systèmes; suivis d'un prodrome général pour tous les mollusques terrestres ou fluviatiles, vivants ou fossiles. $110 \mathrm{pp}$. Paris.

FRÝDA, J. 1997. Oldest representatives of the superfamily Cirroidea (Vetigastropoda) with notes on their early phylogeny. Journal of Paleontology 71(5), 839-847.

FrÝdA, J., BAndel, K. \& FrÝdovÁ, B. 2009a. Crystallographic texture of Late Triassic gastropod nacre: evidence of longterm stability of the mechanism controlling its formation. Bulletin of Geosciences 84(4), 747-756.

DOI 10.3140/bull.geosci.1169

FrÝDA, J. \& BlodgetT, R.B. 1998. Two new cirroidean genera (Vetigastropoda, Archaeogastropoda) from the Emsian (late Early Devonian) of Alaska with notes on the early phylogeny of Cirroidea. Journal of Paleontology 72(2), 265-273.

FrÝdA, J. \& BlodGetT, R.B. 2004. New Emsian (late Early Devo- 
nian) gastropods from Limestone Mountain, Medfra $B-4$ quadrangle, west-central Alaska (Farewell terrane), and their paleobiogeographic affinities and evolutionary significance. Journal of Paleontology 78(1), 111-132.

DOI 10.1666/0022-3360(2004)078<0111:NELEDG >2.0.CO;2

FRÝDA, J. \& FARRELL, J.R. 2005. Systematic position of two Early Devonian gastropods with sinistrally heterostrophic shells from the Garra Limestone, Larras Lee, New South Wales. Alcheringa 29, 229-240. DOI 10.1080/03115510508619303

FrÝdA, J., NÜTZEL, A. \& WAGNER, P.J. 2008. Paleozoic gastropods, 237-268. In Ponder, W. \& Lindberg, D.L. (eds) Phylogeny and Evolution of the Mollusca. 466 pp. University of California Press, Berkeley \& Los Angeles, California.

Frýda, J., Racheboeuf, P.R., Frýdová, B., Ferrová, L., Mergl, M. \& BerkyovÁ, S. 2009b. Platyceratid gastropods - stem group of patellogastropods, neritimorphs or something else? Bulletin of Geosciences 84(1), 107-120.

DOI 10.3140/bull.geosci.1125

FRÝDA, J. \& RoHR, D.M. 2006. Shell heterostrophy in Early Ordovician Macluritella Kirk, 1927, and its implications for phylogeny and classification of Macluritoidea (Gastropoda). Journal of Paleontology 80(2), 264-271.

DOI 10.1666/0022-3360(2006)080[0264:SHIEOM]2.0.CO;2

Fuchigami, T. \& SASAKI, T. 2005. The shell structure of the Recent Patellogastropoda (Mollusca: Gastropoda). Palaeontological Research 9, 143-168. DOI 10.2517/prpsj.9.143

GAULDIE, R.W. 1999. Ultrastructure of lamellae, mineral and matrix components of fish otolith twinned aragonite crystals: implications for estimating age in fish. Tissue Cell 31(2), 138-153. DOI 10.1054/tice.1999.0030

Gauldie, R.W. \& Nelson, D.G.A. 1988. Aragonite twinning and neuroprotein secretion are the cause of daily growth rings in fish otoliths. Comparative Biochemistry and Physiology Part A, Physiology 90(3), 501-509.

DOI 10.1016/0300-9629(88)90227-7

Geiger, D.L., NÜtzel, A. \& Sasaki, T. 2008. Vetigastropoda, 297-330. In Ponder, W. \& Lindberg, D.L. (eds) Phylogeny and Evolution of the Mollusca. 488 pp. University of California Press, Berkeley \& Los Angeles, California.

Giribet, G. 2008. Bivalvia, 105-141. In Ponder, W.F. \& LindBERG, D.R. (eds) Phylogeny and Evolution of the Mollusca. University of California Press, Berkeley.

HedegaArd, C., LindBerg, D.R. \& Bandel, K. 1997. Shell microstructure of a Triassic patellogastropod limpet. Lethaia 30, 331-335. DOI 10.1111/j.1502-3931.1997.tb00477.x

HedegaARD, C. \& WenK, H.-R. 1998. Microstructure and texture patterns of mollusc shells. Journal of Molluscan Studies 64, 133-136. DOI 10.1093/mollus/64.1.133

Jackson, D., McDougall, C., Woodcroft, B., Moase, P., Rose, R., Kube, M., Reinhardt, R., Rokhsar, D., Montagnani, C., Joubert, C., Piquemal, D. \& Degnan, B.M. 2010. Parallel Evolution of Nacre Building Gene Sets in Molluscs. Molecular biology and evolution 27(3), 591-608. DOI 10.1093/molbev/msp278

KIEL, S. \& FRÝDA, J. 2004. Shell structure of Late Cretaceous Sensuitrochus ferreri (Cirridae, Gastropoda). Journal of Paleontology 78(4), 795-797.

DOI 10.1666/0022-3360(2004)078<0795:NILCSF>2.0.CO;2

Klug, C., Kröger, B., Kiessling, W., Mullins, G.L., Servais, T., FrÝdA, J., Korn, D. \& Turner, S. 2010. The Devonian Nekton Revolution. Lethaia 43, 465-477.

DOI 10.1111/j.1502-3931.2009.00206.x
Kouchinsky, A. 2000. Shell microstructures in Early Cambrian molluscs. Acta Palaeontologica Polonica 45(2), 119-150.

KŘiž, J. 2007. Origin, evolution and classification of the new superorder Nepiomorphia (Mollusca, Bivalvia, Lower Paleozoic). Palaeontology 50(6), 1341-1365.

DOI 10.1111/j.1475-4983.2007.00720.x

KŘiž, J. 2008a. A new bivalve community from the lower Ludlow of the Prague Basin (Perunica, Bohemia). Bulletin of Geosciences 83(3), 237-280.

DOI 10.3140/bull.geosci.2008.03.237

Kর̌iž, J. 2008b. Algerina gen. nov. (Bivalvia, Nepiomorphia) from the Silurian of the North Gondwana margin (Algeria), peri-Gondwanan Europe (France, Italy), Perunica (Prague Basin, Bohemia) and the Siberian Plate (Tajmyr Basin, Russia). Bulletin of Geosciences 83(1), 79-84.

DOI 10.3140/bull.geosci.2008.01.079

KŘı̇̌̌, J. \& STEINOVÁ, M. 2009. Uppermost Ordovician bivalves from the Prague Basin (Hirnantian, Perunica, Bohemia). Bulletin of Geosciences 84(3), 409-436.

DOI 10.3140/bull.geosci.1141

LAMARCK, J.B.P.A. DE Monet DE 1799. Prodrome d'une nouvelle classification des coquilles, comprenant une rédaction appropriée des caractères génériques, et l'établissement d'un grand nombre de genres nouveaux. Mémoires de la Société d'Histoire Naturelle de Paris 1 [an VII], 63-91.

LAMARCK, J.P.B.A. DE MoneT DE 1819. Histoire naturelle des animaux sans vertèbres, présentant les caractères généraux et particuliers de ces animaux, leur distribution, leurs classes, leurs familles, leurs genres, et la citation des principales espèces qui s'y rapportent; précédée d'une introduction offrant la détermination des caractères essentiels de l'animal, sa distinction du végétal et des autres corps naturels, enfin, l'exposition des principes fondamentaux de la zoologie. Tome sixième. 343 pp. Paris.

LEACH, W.E. 1814. The zoological miscellany; being descriptions of new, or interesting animals. Illustrated with coloured figures, drawn from nature, by R.P. Nodder. Vol. I. 144 pp. Nodder, London.

Lightfoот, J. 1786. Catalogue of the Portland Museum. 194 pp. London.

LinNAEUS, C. 1758. Systema naturae per regna tria naturae: secundum classes, ordines, genera, species, cum characteribus, differentiis, synonymis, locis. Holmiae: Impensis Direct. 824 pp. Laurentii Salvii.

MacClintock, C. 1968. Shell structure of patelloid and bellerophontoid gastropods (Mollusca). Peabody Museum of Natural History Bulletin 22, 1-140.

ManN, S. 1983. Mineralization in biological systems. Structure and Bonding 54, 125-174. DOI 10.1007/BFb0111320

Marie, B., Luquet, G., Bedouet, L., Milet, C., Guichard, N., Medakovic, D. \& Marin, F. 2008. Nacre Calcification in the Freshwater Mussel Unio pictorum: Carbonic Anhydrase Activity and Purification of a $95 \mathrm{kDa}$ Calcium-Binding Glycoprotein. ChemBioChem 9(15), 2515-2523.

DOI 10.1002/cbic.200800159

Marie, B., Marin, F., Marie, A., Bedouet, L., Dubost, L., Alcaraz, G., Milet, C. \& Luquet, G. 2009. Evolution of nacre: Biochemistry and proteomics of the shell organic matrix of the cephalopod Nautilus macromphalus. ChemBioChem 10(9), 1495-1506. DOI 10.1002/cbic.200900009

Marin, F. \& LuQuet, G. 2004. Molluscan shell proteins. Comptes Rendus Palevol 3, 469-492. DOI 10.1016/j.crpv.2004.07.009 
Marin, F., Luquet, G., Marie, B. \& Medakovic, D. 2008. Molluscan Shell Proteins: Primary Structure, Origin, and Evolution. Current Topics in Developmental Biology 80, 210-277.

Mukai, H., Saruwatari, K., Nagasawa, H. \& Kogure, T. 2010. Aragonite twinning in gastropod nacre. Journal of Crystal Growth 312(20), 3014-3019. DOI 10.1016/j.jcrysgro.2010.07.002

Mutvei, H. 1980. The nacreous layer in molluscan shells, 49-56. In OMori, M. \& WataBe, N. (eds) The mechanisms of biomineralisation in animals and plants. Tokai University Press.

Newell, N.D. 1965. Classification of the Bivalvia. American Museum Novitates 2206, 1-25.

Nishiguchi, M. \& MAPES, R.K. 2008. Cephalopoda, 163-199. In Ponder, W.F. \& LindBerg, D.R. (eds) Phylogeny and Evolution of the Mollusca. University of California Press, Berkeley.

NÜTZEL, A. \& FRÝDA, J. 2003. Paleozoic plankton revolution: evidence from early gastropod ontogeny. Geology 31, 829-831. DOI 10.1130/G19616.1

NÜtZel, A., Lehnert, O. \& FrÝdA, J. 2006. Origin of planktotrophy - evidence from early molluscs. Evolution and Development 8(4), 325-330. DOI 10.1111/j.1525-142X.2006.00105.x

Ouhenia, S., Chateigner, D., Belkhir, M. \& Guilmeau, E. 2008a. Microstructure and crystallographic texture of Charonia lampas lampas shell. Journal of Structural Biology 163, 175-184. DOI 10.1016/j.jsb.2008.05.005

Ouhenia, S., Chateigner, D., Belkhir, M., Guilmeau, E. \& Krauss, C. 2008b. Synthesis of calcium carbonate polymorphs in the presence of polyacrylic acid. Journal of Crystal Growth 310, 2832-2841.

DOI 10.1016/j.jcrysgro.2008.02.006

Parkhaev, P.Y. 2008. The Early Cambrian Radiation of Mollusca, 33-69. In Ponder, W.F. \& LindBerg, D.R. (eds) Phylogeny and Evolution of the Mollusca. University of California Press, Berkeley.

Pokroy, B., Kapon, M., Marin, F., Adir, N. \& Zolotoyabko, E. 2007. Protein-induced, previously unidentified twin form of calcite. Proceedings of the National Academy of Sciences of the United States of America 104(18), 7337-7341. DOI 10.1073/pnas.0608584104

PonDER, W.F. \& LindBERG, D.R. 1997. Towards a phylogeny of gastropod molluscs: an analysis using morphological characters. Zoological Journal of the Linnean Society 119, 83-265. DOI 10.1111/j.1096-3642.1997.tb00137.x

RAFINESQUE, C.S. 1820. Annals of nature or annual synopsis of new genera and species of animals, plants, \&c. discovered in North America. First annual number for 1820.16 pp. Lexington.

RöDING, P.F. 1798. Museum Boltenianum sive catalogus cimeliorum e tribus regnis naturce qua olim collegerat Joa. Fried Bolten, M. D. p. d. per XL. annos proto physicus Hamburgensis. Pars secunda continens conchylia sive testacea univalvia, bivalvia \& multivalvia. 199 pp. Hamburgi.

Rohr, D.M., BLodgetT, R.B. \& FuRNish, W.M. 1992. Maclurina manitobensis (Whiteaves) (Ordovician Gastropoda); the largest known Paleozoic gastropod. Journal of Paleontology 66, 880-884.

RoHR, D.M. \& Gubanov, A.P. 1997. Macluritid opercula (Gastropoda) from the Middle Ordovician of Siberia and Alaska. Journal of Paleontology 71, 394-400.
Rousseau, M., Meibom, A., Geze, M., Bourrat, X., Angellier, M. \& Lopez, E. 2009. Dynamics of sheet nacre formation in bivalves. Journal of Structural Biology 165, 190-195. DOI 10.1016/j.jsb.2008.11.011

RunNegar, B. 1985. Shell microstructures of Cambrian molluscs replicated by phosphate. Alcheringa 9(3-4), 245-257. DOI 10.1080/03115518508618971

SASAKI, T. 1998. Comparative anatomy and phylogeny of the Recent Archaeogastropoda. The University Museum, The University of Tokyo Bulletin 38, 1-223.

Saruwatari, K., Matsui, T., Mukai, H., Nagasawa, H. \& KoGURE, T. 2009. Nucleation and growth of aragonite crystals at the growth front of nacres in pearl oyster, Pinctada fucata. Biomaterials 30, 3028-3034.

DOI 10.1016/j.biomaterials.2009.03.011

SAY, T. 1817. Descriptions of seven species of American fresh water and land shells, not noticed in the systems. Journal of the Academy of Natural Sciences of Philadelphia 1(1-2), 13-17.

SAY, T. 1829. Descriptions of some new terrestrial and fluviatile shells of North America (cont.). The Disseminator of Useful Knowledge; containing hints to the youth of the U. States, from the School of Industry 2(17), 259-261.

SuZuki, M., Saruwatari, K., Kogure, T., Yamamoto, Y., Nishimura, T., Kato, T. \& Nagasawa, H. 2009. An Acidic Matrix Protein, Pif, Is a Key Macromolecule for Nacre Formation. Science 325 (5946), 1388-1390.

DOI 10.1126/science.1173793

SWAINSON, W. 1840. A treatise on malacology, or shells and shell-fish. 419 pp. London.

Ubukata, T. 1994. Architectural constraints on the morphogenesis of prismatic structure in Bivalvia. Palaeontology 37, 241-261.

WADA, K. 1972. Nucleation and growth of aragonite crystals in the nacre of some bivalve molluscs. Biomineralization 1972(4), 141-159.

WAGNER, P.J. 1999. Phylogenetics of the earliest anisostrophically coiled gastropods. Smithsonian Contributions to Paleobiology 88, 1-132.

WISE, S.W. 1970. Microarchitecture and mode of formation of nacre (mother of pearl) in pelecypods, gastropods and cephalopods. Eclogae Geologicae Helvetiae 63, 775-97.

WoodCock, N.H. 1977. Specification of fabric shape using an eigenvalue method. Geological Society of America Bulletin $88,1231-1236$. DOI 10.1130/0016-7606(1977)88<1231:SOFSUA >2.0.CO;2

WoodCOCK, N.H. \& NAYLOR, M.A. 1983. Randomness testing in three-dimensional orientation data. Journal of Structural Geology 5, 539-548. DOI 10.1016/0191-8141(83)90058-5

Weiner, S. \& Traub, W. 1980. X-ray diffraction study of the insoluble organic matrix of mollusk shells. FEBS Letters 111, 311-316. DOI 10.1016/0014-5793(80)80817-9

Weiner, S. \& TRAub, W. 1984. Macromolecules in mollusc shells and their functions in biomineralization. Philosophical Transactions of the Royal Society of London, B 3042, 425-435. DOI 10.1098/rstb.1984.0036

WISE, S.W. 1970. Microarchitecture and mode of formation of nacre (mother of pearl) in pelecypods, gastropods and cephalopods. Eclogae Geologicae Helvetiae 63, 775-797. 